Core Science Systems

\title{
A Comparison of Synthetic Flowpaths Derived from Light Detection and Ranging Topobathymetric Data and National Hydrography Dataset High Resolution Flowlines
}

Open-File Report 2018-1058 



\section{A Comparison of Synthetic Flowpaths Derived from Light Detection and Ranging Topobathymetric Data and National Hydrography Dataset High Resolution Flowlines}

By Cynthia Miller-Corbett

Open-File Report 2018-1058 


\title{
U.S. Department of the Interior \\ RYAN K. ZINKE, Secretary
}

\author{
U.S. Geological Survey \\ James F. Reilly II, Director
}

U.S. Geological Survey, Reston, Virginia: 2018

For more information on the USGS - the Federal source for science about the Earth, its natural and living resources, natural hazards, and the environment-visit https://www.usgs.gov or call 1-888-ASK-USGS.

For an overview of USGS information products, including maps, imagery, and publications,

visit https://store.usgs.gov.

Any use of trade, firm, or product names is for descriptive purposes only and does not imply endorsement by the U.S. Government.

Although this information product, for the most part, is in the public domain, it also may contain copyrighted materials as noted in the text. Permission to reproduce copyrighted items must be secured from the copyright owner.

Suggested citation:

Miller-Corbett, C., 2018, A comparison of synthetic flowpaths derived from light detection and ranging topobathymetric data and National Hydrography Dataset high resolution flowlines: U.S. Geological Survey Open-File Report 2018-1058, 29 p., https://doi.org/10.3133/ofr20181058.

ISSN 2331-1258 (online) 


\section{Acknowledgments}

I would like to thank John Young with the U.S. Geological Survey (USGS) Leetown Water Science Center; Gayla Evans, formerly with the USGS Earth Resources Observation and Science Center; and Jeffrey Danielson with the USGS Coastal National Elevation Database Applications Project for providing the Delaware River light detection and ranging survey digital elevation models to the National Geospatial Program to evaluate extraction of synthetic flowpaths to characterize river system flowpaths.

I especially would like to thank to the National Geospatial Program's 3D Elevation Program and National Geospatial Technical Operations Center for their continued support. 



\section{Contents}

Acknowledgments .......................................................................................................................ii

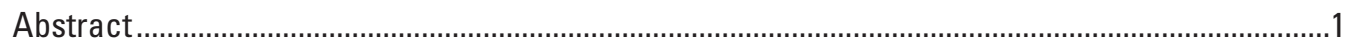

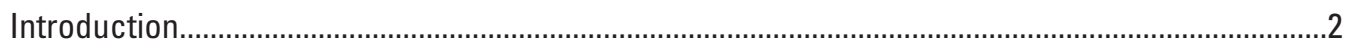

Experimental Advanced Airborne Research Lidar Sensor ................................................................

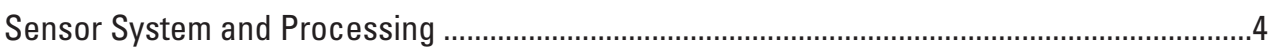

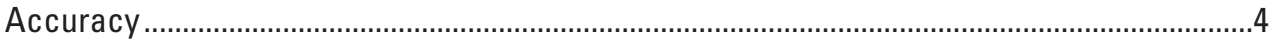

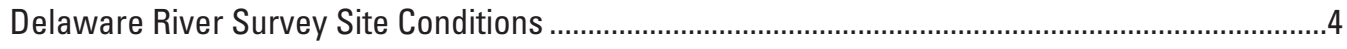

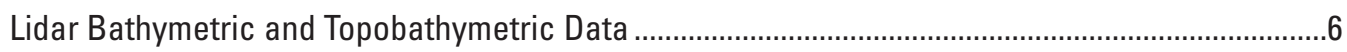

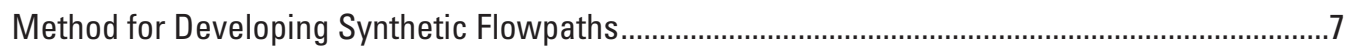

Comparison of Synthetic Flowpaths and National Hydrography Dataset High Resolution

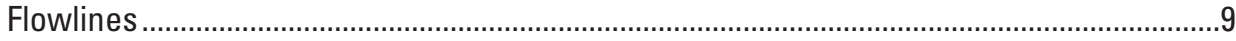

Bathymetric Lidar Synthetic Flowpaths for the Delaware River ............................................9

Synthetic Flowpaths Extracted Using Different Flow Accumulation Thresholds ....................11

Bathymetric Lidar Synthetic Flowpaths at Different Resolutions ..........................................14

Lidar Synthetic Flowpaths and National Hydrography Dataset High Resolution

Flowline Network Correspondence .......................................................................18

Compatibility of Lidar Topobathymetry and 3D Elevation Program Digital Elevation

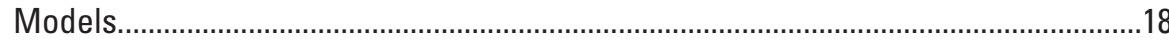

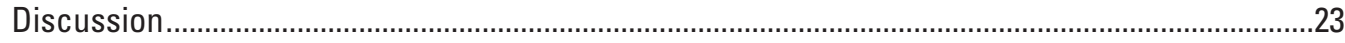

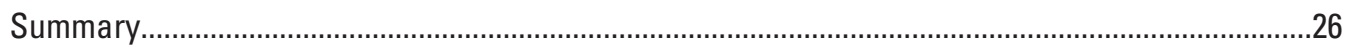

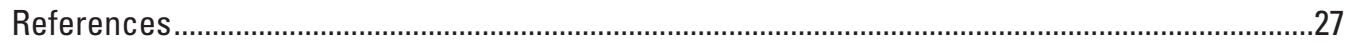

\section{Figures}

1. Map showing Delaware River corridor Hancock Narrows, Middle River, and Trenton light detection and ranging survey groups .......................................................

2. Maps showing intersection of Watershed Boundary Dataset Hydrologic Unit Code 12 boundaries and the Hancock Narrows, Middle River, and Trenton Group reaches of the Delaware River

3. Map showing synthetic flowpath extractions from light detection and ranging digital elevation models.

4. Maps showing distribution of Trenton Group synthetic flowpaths for different flow accumulation threshold values at 10-meter grid-spacing ............................................12

5. Map showing trellis patterned synthetic flowpaths for 10-meter resolution Trenton Group at 0.05 percent of the maximum flow accumulation value

6. Flow direction grids for 1-meter and 10-meter resolution bathymetric light detection and ranging digital elevation models .

7. Maps showing synthetic flowpaths in flat terrain for Trenton Group at 1-meter and 10-meter resolution bathymetric digital elevation models

8. Maps showing synthetic flowpaths for Hancock Narrows Group at 0.05 percent of the maximum flow accumulation for 1-meter, 5-meter, and 10-meter bathymetric light detection and ranging resolutions.

9. Maps showing Hancock Narrows Group D8 flow direction grid for 1-meter and 10-meter bathymetric light detection and ranging digital elevation model resolution 
10. Map showing correspondence between bathymetric light detection and ranging synthetic flowpaths and the High Resolution National Hydrography Dataset Flowline network.

11. Bank slope to river channel bottom without gaps derived from light detection and ranging bathymetric/topobathymetric digital elevation model.

12. Maps showing elevation difference by subtracting 3D Elevation Program digital elevation models from bathymetric light detection and ranging digital elevation models

13. Differences in topobathymetric light detection and ranging and 3D Elevation Program digital elevation model surfaces

\section{Tables}

1. Survey lengths for three resolutions and flow accumulation threshold values

2. Relation of change in area of flow accumulation threshold to create synthetic flowpath segments and grid-cell size

3. Density and distribution of Hancock Narrows Group synthetic flowpaths at variable resolutions and flow accumulation thresholds

\section{Conversion Factors}

International System of Units to U.S. customary units

\begin{tabular}{lcl}
\hline \multicolumn{1}{c}{ Multiply } & \multicolumn{1}{c}{ By } & \multicolumn{1}{c}{ To obtain } \\
\hline centimeter $(\mathrm{cm})$ & Length & \\
meter $(\mathrm{m})$ & 0.3937 & inch (in.) \\
kilometer $(\mathrm{km})$ & 3.281 & foot (ft) \\
kilometer $(\mathrm{km})$ & 0.6214 & mile (mi) \\
meter $(\mathrm{m})$ & 0.5400 & mile, nautical (nmi) \\
& 1.094 & yard (yd) \\
\hline square meter $\left(\mathrm{m}^{2}\right)$ & Area & \\
square kilometer $\left(\mathrm{km}^{2}\right)$ & 0.0002471 & acre \\
square kilometer $\left(\mathrm{km}^{2}\right)$ & 247.1 & acre \\
\hline
\end{tabular}

\section{Datum}

Vertical coordinate information is referenced to the North American Vertical Datum of 1988 (NAVD 88).

Horizontal coordinate information is referenced to the North American Datum of 1983 (NAD 83). 


\section{Abbreviations}

\begin{tabular}{ll} 
3DEP & 3D Elevation Program \\
ALPS & Airborne Lidar Processing System \\
ANPS & aggregate nominal pulse spacing \\
BDEM & bathymetric digital elevation model \\
CI & confidence interval \\
DEM & digital elevation model \\
EAARL & Experimental Advanced Airborne Ranging lidar \\
ESF & extracted synthetic flowpath \\
FAC & flow accumulation threshold \\
FDR & flow direction gridgeodata geospatial data \\
GIS & geographic information system \\
GPS & global positioning satellite \\
HR NHD & High Resolution National Hydrography Dataset \\
HUC & hydrologic unit code \\
IHO & International Hydrographic Organization \\
las & laser data \\
lidar & light detection and ranging \\
MaxFAC & maximum flow accumulation \\
NAIP & National Agricultural Imagery Program \\
NGP & National Geospatial Program \\
NTU & nephelometric turbidity unit \\
OL & quality level \\
RMSE & root mean square error \\
sonar & sound navigation and ranging \\
TauDEM & Terrain Analysis Using Digital Elevation Models \\
tiff & tagged image file format \\
USGS & U.S. Geological Survey \\
WBD & Watershed Boundary Dataset \\
\hline
\end{tabular}





\title{
A Comparison of Synthetic Flowpaths Derived from Light Detection and Ranging Topobathymetric Data and National Hydrography Dataset High Resolution Flowlines
}

\author{
By Cynthia Miller-Corbett
}

\begin{abstract}
Bathymetric and topobathymetric light detection and ranging (lidar) digital elevation models created for the Delaware River were provided to the National Geospatial Program and used to evaluate synthetic flowpath extraction from bathymetric/topobathymetric lidar survey data as a data source for improving the density, distribution, and connectivity of the National Hydrography Dataset High Resolution Flowline Network. As the surface-water component of The National Map, the National Hydrography Dataset maintains the Nation's drainage network flow information and geometries for surfacewater features used in hydrologic, hydraulic, and other science and engineering disciplines. The regional lidar survey for the Delaware River between Hancock, New York, and Trenton, New Jersey, was collected for the U.S. Geological Survey using the Experimental Advanced Airborne Research Lidar sensor system and processed by the Coastal National Elevation Database Applications Program.

Using 1 percent of the maximum flow accumulation value for the surveyed Delaware River corridor as the flow accumulation threshold for grid cells at 1-, 5-, and 10-meter resolution created 223 to 283 kilometers of synthetic flowpaths potentially representing the river channel thalweg, which is the deepest point in a riverbed cross-section. There was potential for improving the High Resolution National Hydrography Dataset (HR NHD) Flowline network in places where the Delaware River channel, depicted as an Artificial Path in the HR NHD, is offset from the extracted synthetic river flowpath which sometimes appeared better positioned than the Artificial Path to represent the river thalweg. For the same area, using 0.05 percent of the maximum flow accumulation at the 1-, 5-, and 10-meter resolutions extracted 744 to 1,317 kilometers of synthetic flowpaths, with extracted synthetic flowpaths representing the main river channel and additional synthetic flowpaths representing tributaries or streams adjacent to the main channel. Overlaying these results with the HR NHDFlowline Network indicates that some of the additional synthetic flowpaths are connected to or extend HR NHD stream/river feature types. Some disconnected or isolated synthetic flowpaths
\end{abstract}

not included in stream/river feature types were validated in orthoimagery and U.S. Topo Maps and provide examples of how extracted synthetic flowpaths could be used to delineate new stream/river features. Other additional extracted synthetic flowpaths depict linear features such as canals, tree lines, roads, or linear topographic depressions.

For some river reaches where obstructions to flow or where low-relief topographic or bathymetric surfaces alter the flow direction, the software tool used to develop the flow direction grid did not calculate a primary flowpath for the river channel. Based on the results of this analysis, site conditions for the Delaware River corridor did not affect the quality of lidar bathymetric survey data. However, depending on the resolution of the lidar bathymetric digital elevation models (BDEMs), site conditions do have different effects on results for extracted synthetic flowpaths. We found that synthetic flowpaths extracted from 1-meter resolution lidar DEMs had more varied flow directions around in-channel landforms that obstructed flow than synthetic flowpaths extracted from 5- or 10-meter resolution lidar DEMs. As a result the 1-meter resolution DEM created some isolated or discontinuous synthetic flowpath segments where the 5- and 10-meter DEMs developed more continuous flowpaths. In this case the river bed upstream from the in-channel obstruction is shallower than the river bed downstream. Under these conditions the 1-meter resolution DEM provided synthetic flowpaths delineating a potential river thalweg. In this same area, the software solution modified (virtually raised) the river bed in the 5- and 10-meter resolution DEMs and flattened the bathymetric surface to create a continuous downstream flow direction, which caused trellis-patterned synthetic flowpaths to form. Under different site conditions and converse to the above development of synthetic flowpaths at different resolutions, at an abandoned river flood plain (terrace) with low relief that is adjacent to the river channel, the flow direction grid for the 1-meter resolution DEM developed continuous synthetic flowpath corresponding to a HR NHD Flowline network stream/river feature that connected to the main river channel but the larger resolution DEMs created isolated or disconnected synthetic flowpaths.

A project to continue an evaluation of benefits of or issues caused by extracting synthetic flowpaths to enhance 
the HR NHD could include a study to assess the potential for merging surface-water flowpaths extracted from lidar topobathymetry and 3D Elevation Program digital elevation models. The merged DEM approach to synthetic flowpath extraction could extend the HR NHDFlowline network and enhance flow accumulations that might develop better flow direction grids in low-relief areas. Because of the confined lateral extent of the Delaware River, the lidar DEMs were not used to create catchments or watersheds; however, the merged DEM approach could also be tested as a resource for enhancing HR NHD catchments and watersheds.

This lidar DEM synthetic flowpath extraction project supports the National Geospatial Program efforts to collect and produce high-quality lidar data to provide 3-dimensional representations of natural feature and aligns with the National Spatial Data Infrastructure to improve utilization of geospatial data. The results also can be useful for understanding strategies that can help maintain quality data in the HR NHD programs.

KEYWORDS: bathymetric, digital elevation model, extracted synthetic flowpath, lidar, High Resolution National Hydrography Dataset, topobathymetric

\section{Introduction}

The purpose of the synthetic flowpath extraction project described here is to evaluate the validity of synthetic flowpaths extracted from light detection and ranging (lidar) bathymetric digital elevation models (BDEMs) and the usefulness of these flowpaths as a digital data source for enhancing the density, distribution, and connectivity of the HR NHDFlowline network. The evaluation is based on a lidar bathymetric survey for three survey areas along the Delaware River Corridor including the Hancock Narrows, Middle River, and Trenton Group (fig. 1). As the surface-water component of The National Map, the National Hydrography Dataset provides a comprehensive geospatial data (geodata) source for surface-water flowline networks with the goal of maintaining accurate data for use in mapping and analysis or modeling of surface-water systems in the United States and its territories. In the conterminous United States, the HR NHDFlowline network was originally developed from digitization of 1:24,000-scale topographic maps and national coverage, and compilation of the HR NHDFlowline network was completed in 2007 (U.S. Geological Survey, 2014a). Since then, the HR NHDFlowline network has been enhanced and updated by the USGS and National Hydrography Dataset Stewards and Partners using areal imagery and other ancillary data sources to include more detailed local resolution content of scales up to $1: 2,400$.

Accurate hydrographic data for flowline networks and water bodies provide surface-water feature geometries fundamental to hydrologic and hydraulic analyses and modeling used in water resource management and science and engineering disciplines (Watkins, 2017; Carlisle and Woodside, 2013).
A useful example of the potential improvement in flowline network accuracy through developing bathymetric lidar is described in the Colson and others (2006), in which lidar hydrography is compared with four other published hydrographic data sources: the HR NHDFlowline network, streams on Natural Resource Conservation Service survey maps, North Carolina Flood Plain Mapping Program stream breaklines, and county geographic information system (GIS) stream layers with streamlines developed from bare earth lidar DEMs. Based on comparisons of each data source to surveyed global positioning satellite (GPS) points, the overall horizontal positional accuracy of streamlines extracted from lidar data was estimated to be between 4 and almost 60 percent better than the other data source accuracies.

Potential benefits for using lidar bathymetry compared to wading or sound navigation and ranging (sonar) surveys can include completing surveys for the same coverage in a shorter time, providing bathymetry for deeper rivers than possible for wading surveys, and collecting more accurate bathymetric data for inland river and lake areas than sonar surveys that may be limited by shallow water or other site conditions that require combined survey systems or multiple passes (U.S. Bureau of Reclamation, 2006; National Park Service, 2011). These potential benefits do not exclude use of wading or sonar survey systems and for some site conditions lidar bathymetry surveys might be used in combination with wading or sonar surveys.

This report presents an overview of the lidar sensor system followed by a description of synthetic flowpath extraction software applications and of site conditions that can affect lidar survey collections or the successful use of synthetic flowpath extraction applications. Results for synthetic flowpath extraction and an analysis of these results are then described. Lastly, a discussion of benefits of and issues caused by using synthetic flowpaths derived from lidar bathymetric data is provided. The airborne bathymetric lidar survey system includes capabilities to collect bathymetric and topobathymetric data; however, the focus of this study is the benefits or potential issues associated with extraction of synthetic flowpaths.

\section{Experimental Advanced Airborne Research Lidar Sensor}

Lidar bathymetric and topobathymetric survey data for the Delaware River were collected using the U.S. Geological Survey (USGS) using the Experimental Advanced Airborne Ranging Lidar (EAARL)-B sensor system. Airborne lidar bathymetry referred to here as "lidar bathymetry" was originally developed in the 1960s for mapping coastal bathymetry (Guenther and others, 2000), and inland river bathymetry applications followed. There are several lidar bathymetric and topobathymetric survey systems designed for shallow and (or) deep water including the EAARL (Wright and others, 2016); Chiroptera II (Leica Geosystems, 2017); Hawkeye III 


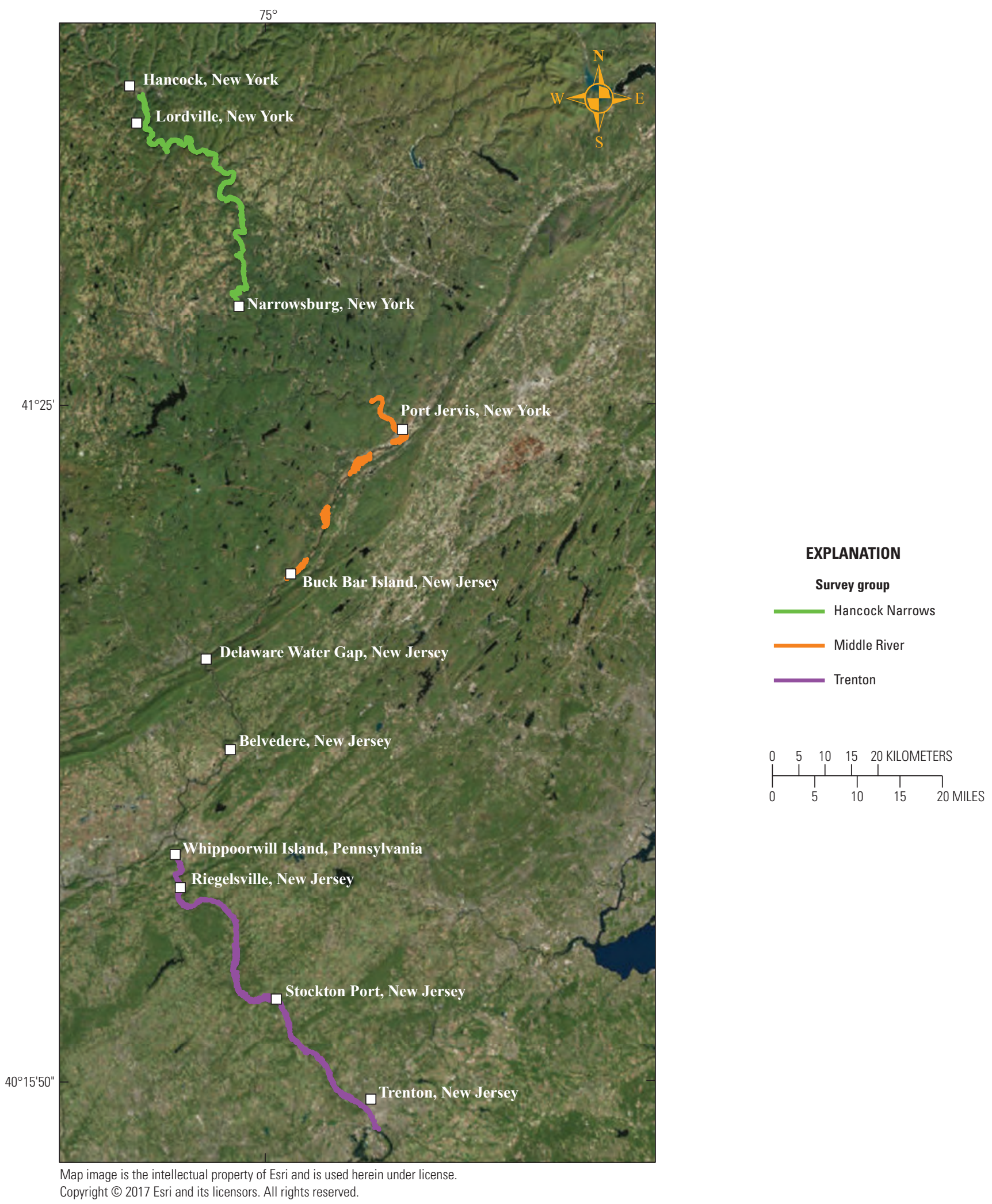

Figure 1. Delaware River corridor Hancock Narrows, Middle River, and Trenton light detection and ranging (lidar) survey groups. 
Synthetic Flowpaths Derived from Light Detection and Ranging Topobathymetric Data and High Resolution Flowlines

(Leica Geosystems AG, part of Hexagon); 2017 Riegl VQ880 (RIEGL Laser Measurement Systems GmbH, 2017); Scanning Hydrographic Operational Airborne Lidar Survey-3000 (Optech Incorporated, 2006); and Coastal Zone Mapping and Imaging Lidar (Teledyne Optech Incorporated, 2017). A compilation of sources for inland bathymetric survey data available as of 2014 indicated that most of the inland bathymetric surveys were completed using acoustic sonar systems, but that surveys using only lidar bathymetric survey systems accounted for 18 percent and surveys using lidar bathymetry in combination with other methods accounted for 20 percent of the referenced surveys (Miller-Corbett, 2016).

The USGS Coastal National Elevation Database Application Projects processed the collected data and ran point correspondence procedures using the Airborne Lidar Processing System (ALPS). The ALPS implements techniques to calculate and interpolate water surface and water feature bottom depths (Bonisteel and others, 2009; U.S. Geological Survey, 2014b).

\section{Sensor System and Processing}

The EAARL-B sensor system includes a raster-scanning, waveform-resolving, green-wavelength (532 nanometers) lidar sensor designed to map nearshore bathymetry, topography, and vegetation structure simultaneously (Wright and others, 2014). The sensor system includes the raster-scanning, water-penetrating, full-waveform adaptive lidar sensor system; downlooking red-green-blue and infrared (1,040 to 1,060 nanometers wavelength) digital cameras; two precision dual-frequency kinematic carrier-phase GPS receivers; and an integrated miniature digital inertial measurement unit, which provide for submeter georeferencing of each laser sample (Wright and others, 2014). Green waveform pulses penetrate the water surface, travel to and reflect off the water feature bottom, and return to the lidar system receiver with less dispersion than lower frequency waveforms used for creating land surface DEMs.

\section{Accuracy}

Vertical and horizontal accuracies for lidar survey data points are calculated using a root mean square error (RMSE) to estimate the standard deviation between the collected data value and an observed, reference value at a 95 -percent confidence interval (CI). In an evaluation of EAARL-B performance, Wright and others (2016) calculated vertical accuracies for EAARL-B with a nominal operating altitude of 300 meters (m) and laser targets with a 30-centimeter $(\mathrm{cm})$ diameter (footprint) to range between $10.4 \mathrm{~cm}$ and $58 \mathrm{~cm}$. These accuracies meet the International Hydrographic Organization (IHO) Special Order and are within or near Order 1 standard requirement for the 95 -percent $\mathrm{CI}$ depth accuracy $(0.56 \mathrm{~m})$ for vertical accuracy down to a $20-\mathrm{m}$ depth. The values also meet or exceed the IHO Order 1 vertical accuracy requirements for depths ranging from 0 to $34 \mathrm{~m}$ (Wright and others, 2016).

Horizontal accuracy for lidar datasets is more difficult to assess than vertical accuracy because land surfaces often lack the well-defined topographic features required for such tests, or because resolution is too coarse to precisely locate distinct surface features (American Society for Photogrammetry and Remote Sensing, 2014). Based on a compilation of EAARL-B surveys reported in Hohenthal and others (2011), horizontal accuracy RMSEs for EAARL-B data that were calculated for 15- and 200-cm laser beam footprints at a 95-percent CI range between 100 and $250 \mathrm{~cm}$; referenced observations used for the calculations were based on observed Real Time Kinematic-GPS data. The horizontal accuracies reported for the EAARL-B system meet American Society for Photogrammetry and Remote Sensing 95-percent CI accuracy requirements for Class 1 digital planimetric data for 1:1,200 to 1:8,000 map scales (American Society for Photogrammetry and Remote Sensing, 2014). When converting the Circular Mapping Accuracy standard of $12.2 \mathrm{~m}$ for a 90-percent CI (Federal Geographic Data Committee, 1998) to the National Standard for Spatial Data Accuracy, the horizontal positional accuracy standard for HR NHD geodata is $13.6 \mathrm{~m}$.

\section{Delaware River Survey Site Conditions}

The Delaware River is characterized as a dendritic flow network for which the overall channel geometry is similar to a branching tree and streams flow downslope to merge at a confluence (Djokic, 2008). Between Hancock, New York, and Trenton, New Jersey, the river channel is about 320 kilometers $(\mathrm{km})$ long and is referenced as the Upper, Middle, and Lower Delaware River (Delaware River Basin Commission, 2014; National Park Service, 2012). These river sections correspond with the lidar bathymetric survey areas, the Hancock Narrows, Middle River, and Trenton Group, respectively (fig. 1). Based on measurements of the lidar bathymetric survey DEMs in a GIS, the average bank-to-bank river width measured about $100 \mathrm{~m}$. In the Hancock Narrows Group area of the Delaware River, several HR NHD Watershed Boundary Datasets (WBDs) with hydrologic unit code (HUC) 12 merge at the river. In the Middle River Group area, elongated WBD HUC $12 \mathrm{~s}$ merge at the northern and midsection of the river. In the Trenton Group, the Delaware River crosses most of the WBD HUC 12 boundaries, with only one group of HUC 12s merging at the river (fig. 2). The range of surveyed area elevations is 198 to $433 \mathrm{~m}$ for the Hancock Narrows Group, 93 to $293 \mathrm{~m}$ for the Middle River Group and -18 to $202 \mathrm{~m}$ for the Trenton Group. The changes in elevation reflect the trend of lower regions moving from the northern limit of the survey at the confluence of the east and west branch of the Delaware River to the southern limit at Trenton, N.J.

In addition to using the appropriate sensor system and supporting equipment for collecting and processing accurate 

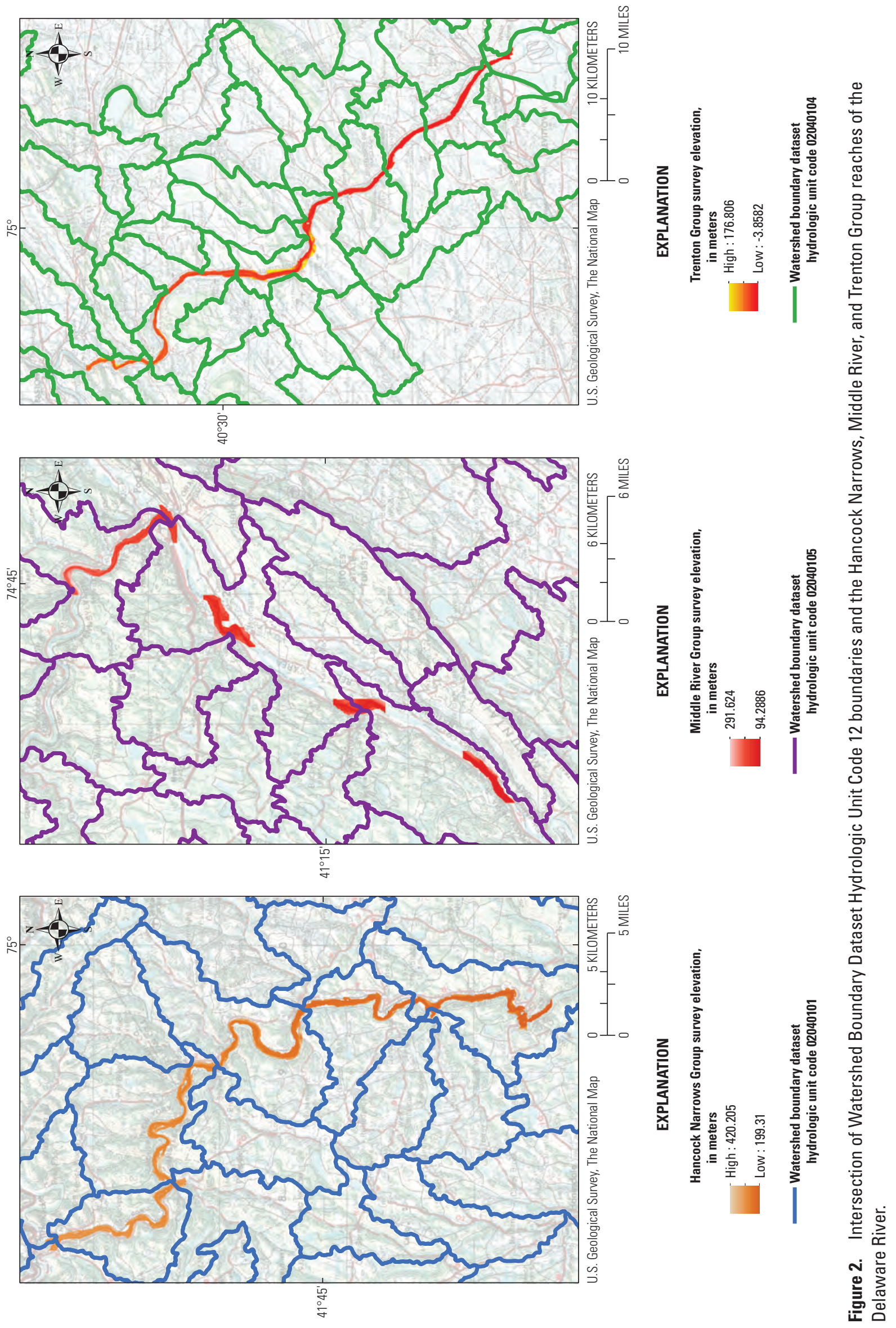
lidar bathymetry, successful inland lidar bathymetry data collection and extraction of useful synthetic flowpaths depends on site conditions. Lidar bathymetric mapping is limited by site conditions such as geomorphology, variable rock grain size that can develop rough or uneven river beds, water depth, turbidity (a measure of relative water clarity), and vegetation that may cause dispersion or loss of signals (Feurer and others, 2008; Guenther and others, 2000; Hohenthal and others, 2011; Kinzel and others, 2013; National Park Service, 2011). The inclusion of data to attribute these physical parameters as part of lidar bathymetric and topobathymetric survey information is important for better understanding and relating site conditions that affect the quality of lidar bathymetric and topobathymetric data collection and processing.

From the northern section of the survey near Hancock, N.Y., to the southern end of the Middle River Group, the river flows through the Appalachian Plateau and Valley and Ridge Province(s) (not shown) and the river bed consists of fine to coarse grained clastics and compacted clastics forming siltstone, sandstone, and shale and conglomerates (U.S. Geological Survey, 2013b). South of the Middle River Group, the river channel flows through the Delaware Water Gap. This region includes a suite of folded and faulted rock layers (Pennsylvania Department of Natural Resources, 2014; U.S. Geological Survey, 2003; National Park Service, 2012) and was not included as part of the lidar survey. Beginning at the northern end of the Trenton Group and continuing to the southern end at Trenton, N.J., the Delaware River flows through the Piedmont Province. This section of the river channel bed includes a mix of clastic and compacted sedimentary rocks, as well as some swamp deposits (U.S. Geological Survey, 2013b).

Water depths for the Delaware River are variable. In the Hancock Narrows Group at Narrowsburg, N.Y., (fig. 1) the river bed depth has been measured as $33 \mathrm{~m}$ (White and Kratzer, 1993) The National Park Service indicates some pools are 30 or $35 \mathrm{~m}$ deep (National Park Service, 2012). Based on using river stage data, which the USGS Water Science School reports to approximate water depths (U.S. Geological Survey, 2016a), there are also many places where the river channel is very shallow. For example, in places such as Lordville, N.Y., the Delaware Water Gap, N.J., and Trenton, N.J., water depths can be less than $1 \mathrm{~m}$ to about $2 \mathrm{~m}$ (U.S. Geological Survey, 2017).

The EAARL-B system includes shallow and deep water receivers designed to collect bathymetric data at reported Delaware River bed depth ranges. The shallow water channel receiver can map optically shallow, clear water ranging in depth from 0 to approximately $20 \mathrm{~m}$, and the deep water channel receiver can collect bathymetric data at depths ranging from 15 to $44 \mathrm{~m}$ (Wright and others, 2016). Because of this wide range of depth collection, the survey system is suited for targeting the Delaware River bottom and receiving quality return signals.

Turbidity is measured in nephelometric turbidity units (NTUs). NTUs less than 10 indicate clear water (U.S. Geological Survey, 2016a). Compiled water quality data, including turbidity measurements for the Delaware River from Hancock, N.Y., to the Delaware River Water Gap, include values ranging between about 2 and 4 NTUs (Delaware River Basin Commission, 2013). Water data for sections of the Delaware River include values ranging from less than 3 NTUs on the Pennsylvania side of the river at Trenton, N.J., and as high as 9.5 NTUs at a streamgage between Riegelsville, Pennsylvania, and Stockton, N.J. (U.S. Geological Survey, 2017). All values are within the range of clear water NTU values.

\section{Lidar Bathymetric and Topobathymetric Data}

The USGS contracted the EAARL-B sensor system survey in 2014 to collect bathymetric and topobathymetric elevation data for more than $280 \mathrm{~km}$ of the Delaware River channel corridor between Hancock, N.Y., and Trenton, N.J. (fig. 1). Based on measurements of the lidar bathymetric survey DEMs, the main river channel averages about $100 \mathrm{~m}$ wide. The width of the lidar DEM footprint centered along the main river channel varied between 300 and $500 \mathrm{~m}$. Data are spatially referenced to the World Geodetic System 1984 spheroid and projected in Universal Transverse Mercator Coordinate System, Zone 18. The aggregate nominal pulse spacing (ANPS) is $0.61 \mathrm{~m}, 0.62 \mathrm{~m}$, and $0.71 \mathrm{~m}$ for the Hancock Narrows, Middle River, and Trenton Groups, respectively. All aggregate nominal pulse density values meet the USGS lidar specification for quality level (QL) 2 of greater than or equal to 2.0 points per square meter (Heidemann, 2014).

The USGS Coastal National Elevation Database Applications Program processed the bathymetric and topobathymetric lidar data using Airborne Lidar Processing software. Delaware River bathymetric and topobathymetric lidar DEMs were provided to the National Geospatial Program (NGP) in laser data (las) file format and tagged image file format (tiff) for three survey groups. The Hancock Narrows Group is the northern group that runs from the confluence of the East Branch Delaware River and West Branch Delaware River at Hancock, N.Y., to Narrowsburg, N.Y.; raster tile coverage is 859 square kilometers. The Middle River Group covers the river corridor from northwest of Port Jervis, N.Y., to south of Buck Bar Island, N.J. This group covers 800 square kilometers. The southern survey group is the Trenton Group. This group covers the river from Whippoorwill Island, Pa., to Trenton, N.J., just north of the National Oceanic and Atmospheric Administration Harbor Chart for the Delaware River (National Oceanic and Atmospheric Administration, National Ocean Service, 2012). 


\section{Method for Developing Synthetic Flowpaths}

Bathymetric and topobathymetric lidar DEMs for the Delaware River Hancock Narrows, Middle River, and Trenton Groups were provided at 1-meter resolution and resampled at 5-meter and 10-meter resolution to evaluate results for developing synthetic flowpaths at different grid spacing. Synthetic flowpaths from the three lidar DEM resolutions were extracted by creating stream segments based on specifying a minimum flow accumulation threshold (FAC) for grid cells using ArcHydro program routines (tools) implemented in Esri GIS software (Djokic, 2008).Varying the grid spacing and the FAC created synthetic flowpaths at different densities and distributions, providing simple to more complex synthetic flowpath geometries.

The flow direction grid (FDR) application is the fundamental tool for developing synthetic flowpaths, referred to as drainlines in the ArcHydro software program (fig. 3). Depending on topographic relief, different software applications are used to manipulate elevation data to minimize extracted synthetic flowpath (ESF) termination in elevation grid low points, or to control the synthetic flowpath and successfully develop an FDR. The Fill Sinks tool is commonly used for treating dendritic flowline networks and was used in this study to derive hydrography from the dendritic Delaware River lidar survey DEMs. The Fill Sinks tool fills depressions (sinks) based on an automatic or user-specified Z-limit, which is the maximum difference in elevation between the local pour point and depth of a cell of interest. When the Z-limit is larger than the elevation difference, the depression will be filled; when the Z-limit is smaller, the sinks will not be filled because the depth exceeds the difference and is considered a valid sink (Esri, 2014). Without filling sinks, the FDR tool used to assign flow away from each grid cell to one of eight neighboring cells incorrectly creates a grid with additional flow directions and cannot be used as input to the subsequent routine.

Other ArcHydro software functions that can be used to treat a DEM that depicts other drainage systems prior to implementing the sequence of routines include the Prescreen Sinks, Level DEM, Reconditioning, Stream Burning, and Building Walls applications. These functions are designed to better derive synthetic flowpaths in deranged terrain that contains only depressions (sinks), in terrain that is a combination of dendritic and deranged types, or for other topographical conditions that may make it hard to identify changes in the slope between neighboring grid cells, which is the basis for developing flow directions (Esri, 2014; Esri, 2011; 2013; Merwade, 2012).

Flow direction grid.-FDRs depict the calculated flow direction out of each raster grid cell. Initially, ArcHydro and the Terrain Analysis Using Digital Elevation Models (TauDEM) software program were used in trial runs to derive the FDR using the D8 tool flow model solution developed by Jenson and Dominque (1988). The D8 tool is used to calculate the steepest slope from each DEM grid cell to all eight neighboring cells to solve for the primary direction of flow (Merwade, 2012). TauDEM also implements the D-Infinity solution that was used in the trial runs. This method for creating an FDR calculates a flow direction as a single angle defined for the steepest downward slope on eight triangular facets centered at each grid point (Tarboton, 1991).

In a comparison of the results for ArcHydro D8 and TauDEM D-Infinity flow direction tools used to extract synthetic flowpaths in different terrains and at different resolutions in North Carolina, Colson and others (2006) calculated accuracies for the two stream-extraction techniques and concluded there was little or no differences in results where accuracies were calculated as the number of survey points within a $3-\mathrm{m}$ buffer for the stream reaches of interest. The differences that were identified were attributed to the different flow routing algorithms used by each solution (Colson and others, 2006) but overall TauDEM did provide better accuracies. Results for the Colson and others (2006) study indicated that the TauDEM software consistently developed flowlines with better accuracy for the 1.52-m resolution DEMs. For 6-m resolution DEMs, TauDEM had significantly better accuracy for one site and was 7 percent better or comparable for the other three sites. TauDEM flowlines for 10-m resolution DEMs had accuracies comparable to the ArcHydro stream extraction tool. For both stream-extraction tools, accuracies dropped as the DEM cell size increased. Also for both tools, accuracies were best in irregular plain topography with a physiography of low rounded ridges and shallow ravines. The worst accuracies were calculated for low-relief plains.

During the initial stage of the stream extraction evaluation described in this report, the TauDEM D-Infinity tool was used for a section of the Delaware River and compared with the results for running the ArcHydro D8 tool for synthetic flowpath extraction. Synthetic flowpaths derived using the D-Infinity tool showed more realistic channel or tributary curvature than those derived using the D8 solution; however, for this site the geometry for flowlines developed using D-Infinity appeared similar to the geometry for flowlines derived using ArcHydro D8 functionality. Because the initial evaluation of lidar hydrography was done using the ArcHydro D8 application and because results from the two processes are similar, the D8 solution is used in this project. However, testing to develop a quantitative comparison between ArcHydro and TauDEM stream extraction techniques is recommended to be confident that the software program used for lidar synthetic flowpaths will produce the best results for accurate, valid delineation of hydrographic features.

Flow accumulation and stream definition.-The FDR is input to a flow accumulation tool that calculates the number of upstream cells flowing into a downstream cell and creates a flow accumulation grid. Next, the Stream Definition tool is used to create stream segments (synthetic flowpaths) from the flow accumulation grid.

The stream definition value is the number of upslope cells required to flow into a grid cell for the receiving cell 


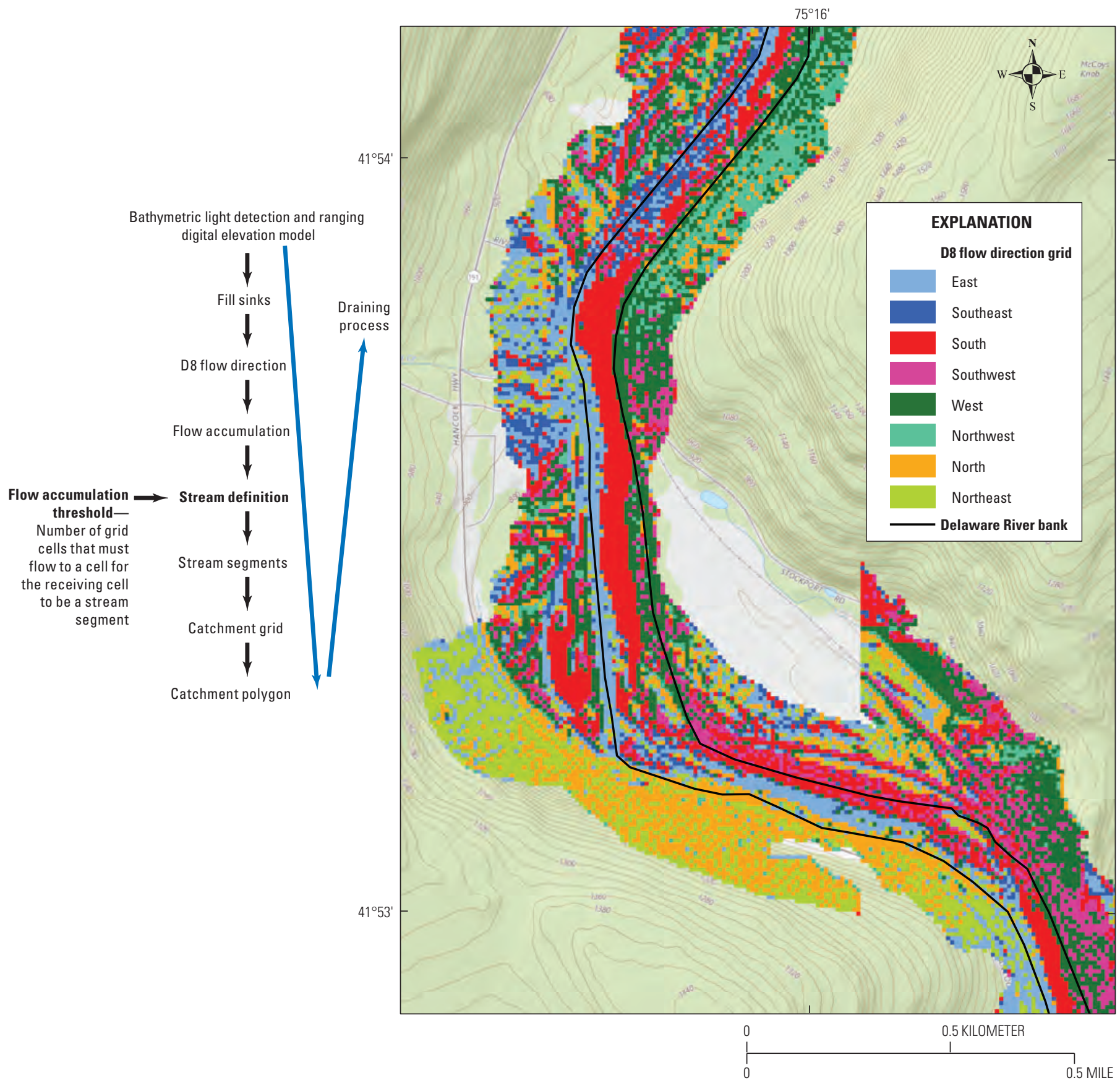

Figure 3. Synthetic flowpath extractions from light detection and ranging (lidar) digital elevation models.

to qualify as a stream segment of a synthetic flowpath, and is better known as the flow accumulation threshold FAC. Using ArcHydro, the Stream Definition tool automatically provides 1 percent of the maximum FAC (MaxFAC) value, which is the maximum number of cells calculated to flow to a receiving cell in a DEM as the default stream definition value. For the Delaware River system, using 1 percent of the MaxFAC extracted the main river channel. The FAC to develop the main river channel and additional, associated stream/river (tributary) features is a smaller percentage of the MaxFAC value. The percent of the MaxFAC value that will be used to create the most useful synthetic flowpath network will depend on site conditions and resolution and the density of synthetic flowpaths required for user needs. The size of a watershed also affects synthetic flowpath development, and another approach for evaluating stream definition is to calculate FACs as the area upstream from receiving cells in order to analyze or model surface-water flow (L. Stanislawski, U.S. Geological Survey, written commun., 2017). 
Stream segment and subsequent routines.-Once the Stream Definition is complete, the sequence of ArcHydro applications to develop synthetic flowpaths is Stream Segment, Catchment Delineation, Catchment Polygon, and Flowline Processing routines. The two catchment tools are not needed to develop synthetic flowpaths but are necessary for creating watersheds. Capabilities for developing watersheds that use flowlines and catchments in ArcHydro were tested; however, compared with the scale of the HR NHD Watershed Boundary HUC 12 polygons, the relatively narrow corridor for the lidar bathymetric/topobathymetric survey, which resulted in narrow watersheds confined to the limits of the surveyed areas, did not allow a useful evaluation of lidar watersheds and HR NHD WBDs.

Bathymetric lidar synthetic flowpaths created from different lidar DEM resolutions and at different FAC values are overlain with HR NHDFlowline network HUC 8 datasets (U.S. Geological Survey, 2013a) to evaluate similarities and differences. Using 1 percent of the MaxFAC usually develops synthetic flowpaths that correlate with the main Delaware River channel depicted in the HR NHDFlowline network as Artificial Path vector data. Smaller MaxFAC percentages used to develop smaller FACs create synthetic flowpaths in addition to the main river channel delineation. These synthetic flowpaths represent tributaries or first order stream equivalents identified as HR NHDFlowline network stream/river feature types.

Synthetic flowpaths were further evaluated and validated by overlaying with 3D Elevation Program (3DEP) 10-m resolution DEMs, which for this region are all derived from lidar data (U.S. Geological Survey, 2016c), and 2013 to 2015 orthoimagery at 1-meter resolution available from the National Agricultural Imagery Program (NAIP) (Esri, 2015). Synthetic flowpaths that were not included in the HR NHDFlowline network are assessed to see if these could be used to enhance the density, distribution, and connectivity of the HR NHDFlowline network feature types.

\section{Comparison of Synthetic Flowpaths and National Hydrography Dataset High Resolution Flowlines}

In the HR NHDFlowline network, the Artificial Path feature type is used to delineate the Delaware River channel flowlines. Artificial Paths are surrogates for the general flow direction of HR NHDFlowline network stream/river feature types. Single-line Artificial Paths represent stream/river feature types
$12.2 \mathrm{~m}$ wide but less than $183 \mathrm{~m}$ that approximate the center line for assumed and generalized flow through a 2-dimensional feature such as a lake or a wide double-banked (polygon) stream/river features (U.S. Geological Survey, 2016b). Stream/river features greater than that are $12.2 \mathrm{~m}$ (40 feet) wide and continuous for at least $183 \mathrm{~m}$ (600 feet) are doubleline Artificial Paths (U.S. Geological Survey, 2016b). Artificial paths also are used to approximate the center line for closed water bodies that either fall on a streamline, or closed water bodies that are the origin or source of a flow path. Tributaries and creeks are categorized as stream/river feature types. Other flowline feature types in the study area include canal/ditches (constructed open waterways), pipelines (closed conduits), and connectors that are nonvisible lines used to connect two nonadjacent network segments.

\section{Bathymetric Lidar Synthetic Flowpaths for the Delaware River}

The combined length of channels extracted from lidar BDEMs for the Hancock Narrows, Middle River, and the Trenton Groups depends on the FAC values and the resolution of the lidar BDEM. Total lengths of synthetic flowpaths resulting from 1-meter grid spacing are always greater than for the other resolutions at the same FAC. Generally, resulting lengths are similar for 5- and 10-m resolutions at the same FAC. For 1-, 5-, and 10-meter resolution DEMs, using 1 percent of the MaxFAC, which creates the main river channel, the total combined length of synthetic flowpaths for the three study groups ranged between 223 and $283 \mathrm{~km}$ (table 1). Using 0.05 percent of the MaxFAC for the three DEM resolutions, the combined lengths for the three survey groups vary between about 744 and $1,317 \mathrm{~km}$. These totals include the extracted river channel and additional synthetic flowpaths that are distributed along the length of the survey and within the surveyed river corridor. Review of table 2 which presents the FAC areas for the Hancock Narrows, Middle River, and Trenton Group(s) at different FAC values shows an increase in the FAC area with an increase in grid cell size, even though the number of cells decreases (table 3 ). This means that synthetic flowpaths extracted from a 1-meter resolution lidar bathymetric DEM will be more densely distributed but cover less area than the 5or 10-m resolution lidar bathymetric DEM. Which lidar DEM resolution is best may depend on site conditions that can affect how well created stream segments connect to develop continuous synthetic flowpaths, and on individual user needs.

The geometries for synthetic flowpaths extracted at different resolutions can be similar but offset from one another. 
Table 1. Survey lengths for three resolutions and flow accumulation threshold values.

[FAC, flow accumulation threshold; lidar, light detection and ranging; MaxFAC, maximum flow accumulation; \%, percent]

\section{Delaware River bathymetry lidar survey group lengths}

\begin{tabular}{|c|c|c|c|c|c|c|c|c|c|}
\hline & \multicolumn{3}{|c|}{ Hancock Narrows Group } & \multicolumn{3}{|c|}{ Middle River Group } & \multicolumn{3}{|c|}{ Trenton Group } \\
\hline \multirow{3}{*}{$\begin{array}{c}\text { FAC } \\
\text { (percent of } \\
\text { MaxFAC) }\end{array}$} & \multicolumn{3}{|c|}{ Grid cell size, in meters } & \multicolumn{3}{|c|}{ Grid cell size, in meters } & \multicolumn{3}{|c|}{ Grid cell size, in meters } \\
\hline & 1 & 5 & 10 & 1 & 5 & 10 & 1 & 5 & 10 \\
\hline & \multicolumn{3}{|c|}{ Length, in meters } & \multicolumn{3}{|c|}{ Length, in meters } & \multicolumn{3}{|c|}{ Length, in meters } \\
\hline
\end{tabular}

Table 2. Relation of change in area of flow accumulation threshold to create synthetic flowpath segments and grid-cell size.

[FAC, flow accumulation threshold; MaxFAC, maximum flow accumulation; \%, percent]

Area of flow accumulation threshold to create flowpath segment

\begin{tabular}{|c|c|c|c|c|c|c|c|c|c|}
\hline & \multicolumn{3}{|c|}{ Hancock Narrows Group } & \multicolumn{3}{|c|}{ Middle River Group } & \multicolumn{3}{|c|}{ Trenton Group } \\
\hline \multirow{3}{*}{$\begin{array}{c}\text { FAC } \\
\text { (percent of } \\
\text { MaxFAC) }\end{array}$} & \multicolumn{3}{|c|}{ Grid cell size, in meters } & \multicolumn{3}{|c|}{ Grid cell size, in meters } & \multicolumn{3}{|c|}{ Grid cell size, in meters } \\
\hline & 1 & 5 & 10 & 1 & 5 & 10 & 1 & 5 & 10 \\
\hline & \multicolumn{3}{|c|}{ Area, in square meters } & \multicolumn{3}{|c|}{ Area, in square meters } & \multicolumn{3}{|c|}{ Area, in square meters } \\
\hline $0.15 \%$ & 20,443 & 37,275 & 141,300 & 4,116 & 8,675 & 8,400 & 13,051 & 53,625 & 153,400 \\
\hline $0.05 \%$ & 6,814 & 12,425 & 13,700 & 1,372 & 2,875 & 2,900 & 4,305 & 17,875 & 18,100 \\
\hline
\end{tabular}


Table 3. Density and distribution of Hancock Narrows Group synthetic flowpaths at variable resolutions and flow accumulation thresholds

[lidar, light detection and ranging; MaxFAC, maximum flow accumulation]

Comparison of synthetic flowpath extraction at three solutions for the Hancock Narrows Group

\begin{tabular}{|c|c|c|c|}
\hline & $\begin{array}{l}\text { 1-meter resolution } \\
\text { lidar-derived drainlines }\end{array}$ & $\begin{array}{l}\text { 5-meter resolution } \\
\text { lidar-derived drainlines }\end{array}$ & $\begin{array}{l}\text { 10-meter resolution } \\
\text { lidar-derived drainlines }\end{array}$ \\
\hline $\begin{array}{l}\text { Flow } \\
\text { accumulation } \\
\text { threshold }\end{array}$ & MaxFAC $13,628,908$ cells & MaxFAC 994,642 cells & MaxFAC 227,286 cells \\
\hline \multicolumn{4}{|c|}{ Synthetic flowpath distribution } \\
\hline $\begin{array}{l}\text { 1-percent } \\
\text { MaxFAC }\end{array}$ & $\begin{array}{l}\text { River channel discontinuous along some } \\
\text { reaches and around in-channel islands. } \\
63 \text { extracted flowlines }\end{array}$ & $\begin{array}{l}\text { River channel discontinuous along some } \\
\text { reaches and around in-channel islands. } \\
22 \text { extracted flowlines }\end{array}$ & $\begin{array}{l}\text { River channel continuous except } \\
\text { around in-channel islands. } \\
21 \text { extracted flowlines. }\end{array}$ \\
\hline $\begin{array}{c}\text { 0.05-percent } \\
\text { MaxFAC }\end{array}$ & $\begin{array}{l}\text { River channel continuous. Additional } \\
\text { flowline correlations with NHDHR } \\
\text { Many additional isolated and con- } \\
\text { nected flowlines } \\
\text { Trellis patterns } \\
\text { 2,565 extracted flowlines }\end{array}$ & $\begin{array}{l}\text { River channel continuous except at in- } \\
\text { channel islands. Additional flowline } \\
\text { correlations with NHDHR. Additional } \\
\text { connected and isolated flowlines } \\
\text { Trellis patterns } \\
\text { 1,292 extracted flowlines }\end{array}$ & $\begin{array}{l}\text { River channel continuous Addi- } \\
\text { tional flowlines correlations with } \\
\text { NHDHR Additional connected and } \\
\text { some isolated flowlines } \\
\text { Trellis-patterned flowlines } \\
\text { 1,143 extracted flowlines. }\end{array}$ \\
\hline
\end{tabular}

\section{Synthetic Flowpaths Extracted Using Different Flow Accumulation Thresholds}

For 1-, 5-, and 10-m resolution lidar BDEMs, using 1 percent of the MaxFAC usually creates the synthetic flowpath representing the main Delaware River channel though for 1-meter resolution additional synthetic flowpaths sometimes develop. Decreasing the FAC from 1 percent of the MaxFAC to smaller values creates additional stream/river feature types delineating tributaries and other surface-water flowlines. Decreasing the FAC often creates additional synthetic flowpaths that extend those created at higher FAC values, but also creates isolated or disconnected synthetic flowpaths. Testing a range of FACs showed that using 0.05 of the MaxFAC consistently developed synthetic flowpaths representing the Delaware River channel, Delaware River tributaries, new synthetic flowpaths connected to the river, and other additional synthetic flowpaths proximal to HR NHDFlowline network that could be further assessed for enhancing the distribution and connectivity of surface-water flowline features.

Results for a section of the Trenton Group 10-m resolution data show how creating synthetic flowpaths at 1 percent of the MaxFAC delineates the Delaware River channel along the lowest extracted river channel bathymetry, representing part of the current or a previous thalweg position (fig. 4). Lowering the $\mathrm{FAC}$ to 0.05 percent of the MaxFAC created a denser and more continuous network of synthetic flowpaths that extend the main river channel and stream/river features created at the larger FAC, and also developed synthetic flowpaths that match with tributaries identified as HR NHDFlowline network stream/river features (fig. 4). The total length of ESFs using 1 percent is $89 \mathrm{~km}$ and using 0.05 percent, it is $247 \mathrm{~km}$. In some places, synthetic flowpaths extracted from lidar BDEMs form trellis-patterned flowlines (fig. 5). Formation of trellis-patterned flowlines can happen in flat-bottomed or near to flat-bottomed river reaches, or in river sections behind (upstream from) human-made or natural obstructions that alter downstream directed flow. The trellis-patterned flowlines also may develop in areas where a downstream river reach has a higher channel bottom with a shallower water depth than a proximal upstream reach, such as what is shown in figure 5 when 0.05 percent of the MaxFAC was used to create synthetic flowpaths. At this site a weir has changed the expected downstream flow direction of the synthetic flowpath and a trellis pattern with multiple parallel lineaments depicting synthetic flowpaths developed upstream from the weir. Crosssection profiles indicate that the lidar BDEM depicts several quasi-parallel shallow (less than $1 \mathrm{~m}$ ) elevation changes in a ridge-trough type surface for the upstream river bed bathymetry and that the software solution did not identify any of the troughs as synthetic flowpaths. Under the altered flow conditions, the software algorithm fills or raises the upstream, deeper pool and creates a flat surface where the trellis pattern forms. At the site in figure 5, changing the FAC from 0.05 percent to 0.15 percent and 1.0 percent of the MaxFAC simplifies the synthetic flowpath pattern, creating only the outer limbs of the trellis pattern using 0.05 percent. The outer lineament on the east delineates the deepest synthetic flowpath or potential thalweg and the outer, western lineament overlies a ditch or canal depicted as an HR NHDFlowline network Artificial Path. Although using the bigger FAC values can avoid the 


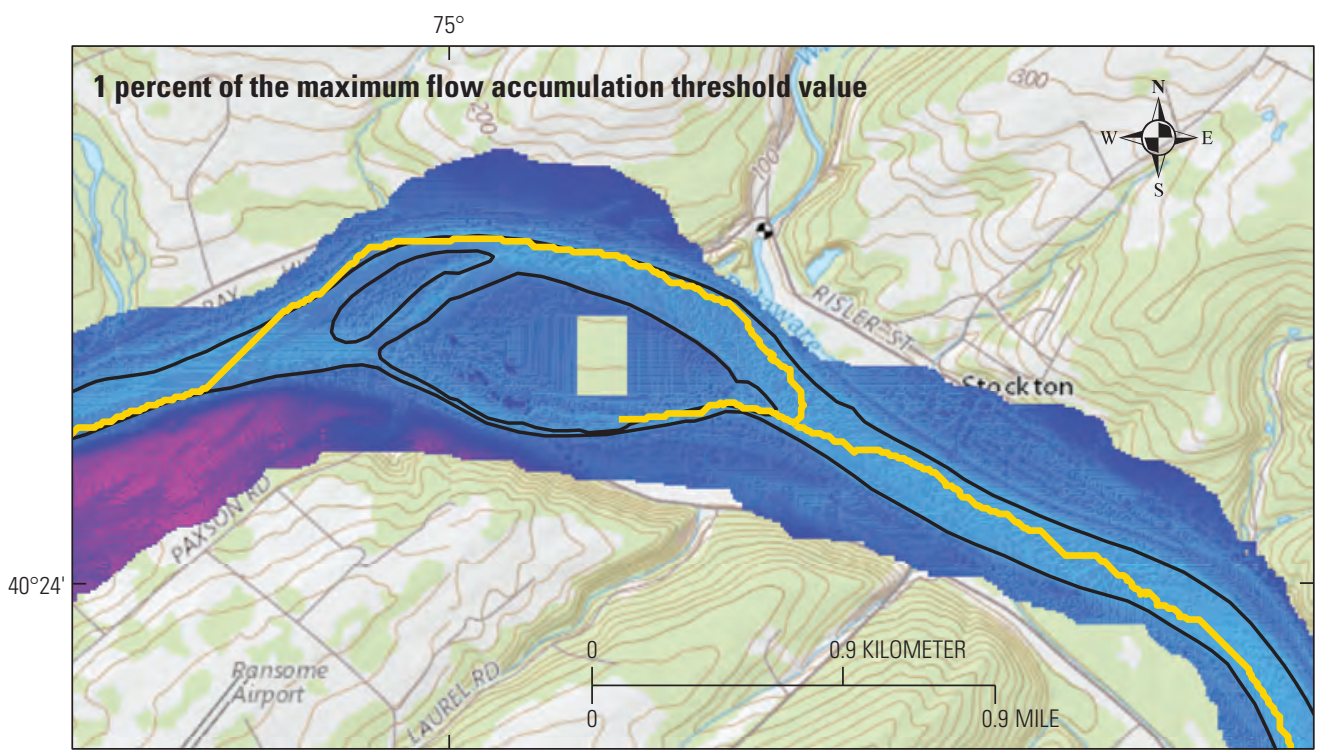

U.S. Geological Survey, The National Map

$75^{\circ}$

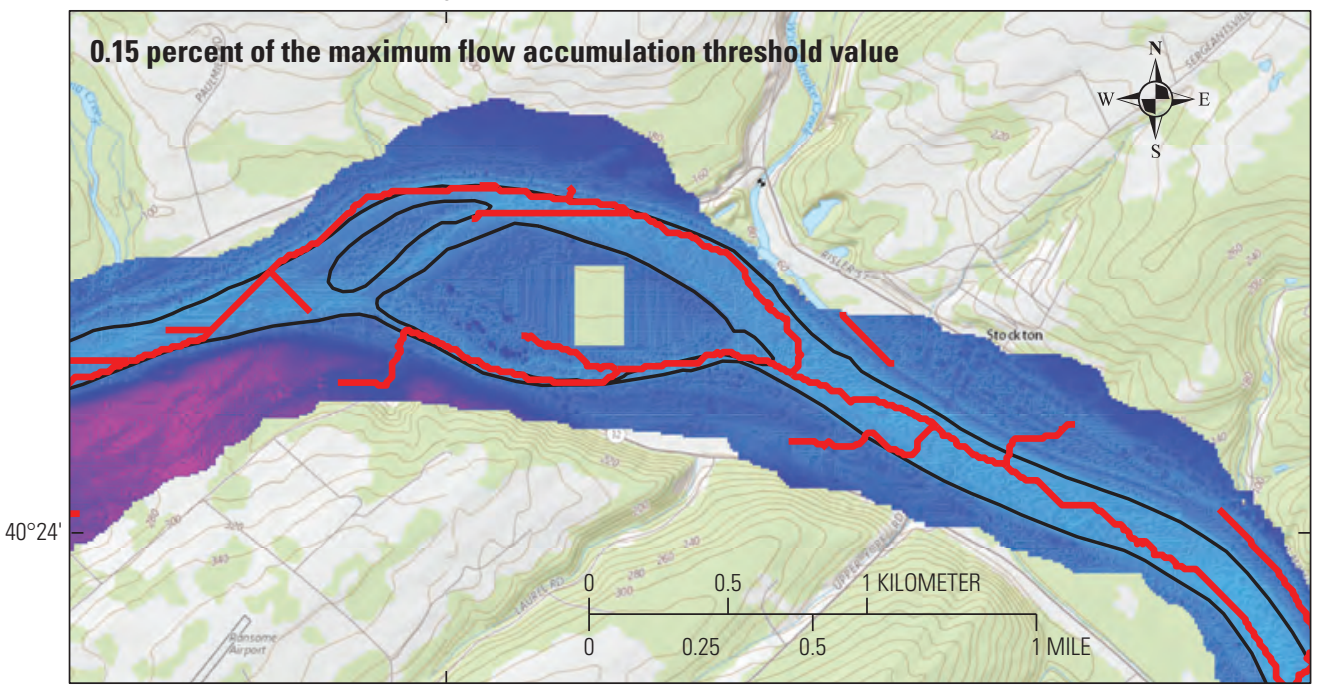

U.S. Geological Survey, The National Map

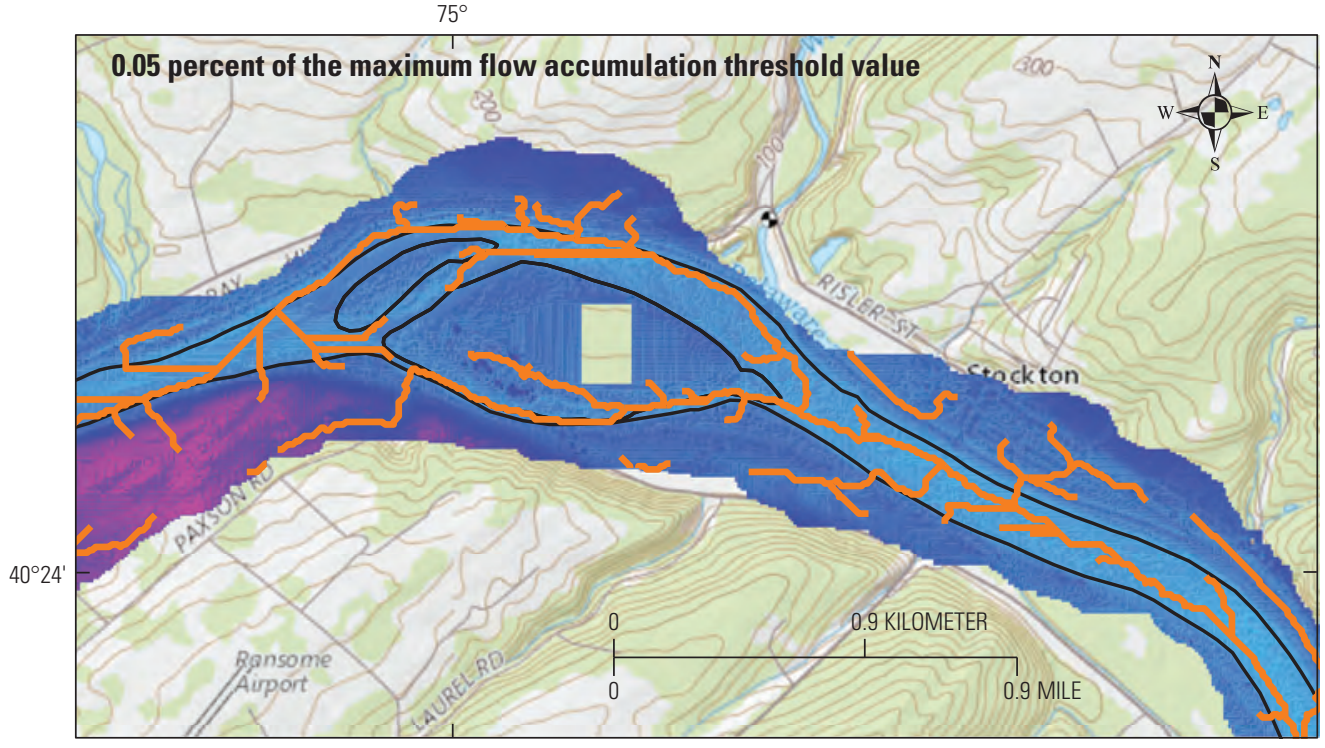

U.S. Geological Survey, The National Map

\section{EXPLANATION}

Trenton Group elevation, in meters

176.806

158.74

140.673

122.607

104.54

86.4739

68.4075

50.3411

32.2746

14.2082

$-3.8582$

Synthetic flowpaths for 10-meter grid-spacing

1.0 percent of flow accumulation threshold

0.15 percent of flow accumulation threshold

0.05 percent of flow accumulation threshold

River bank
Figure 4. Distribution of Trenton Group synthetic flowpaths for different flow accumulation threshold values at 10-meter grid-spacing. 


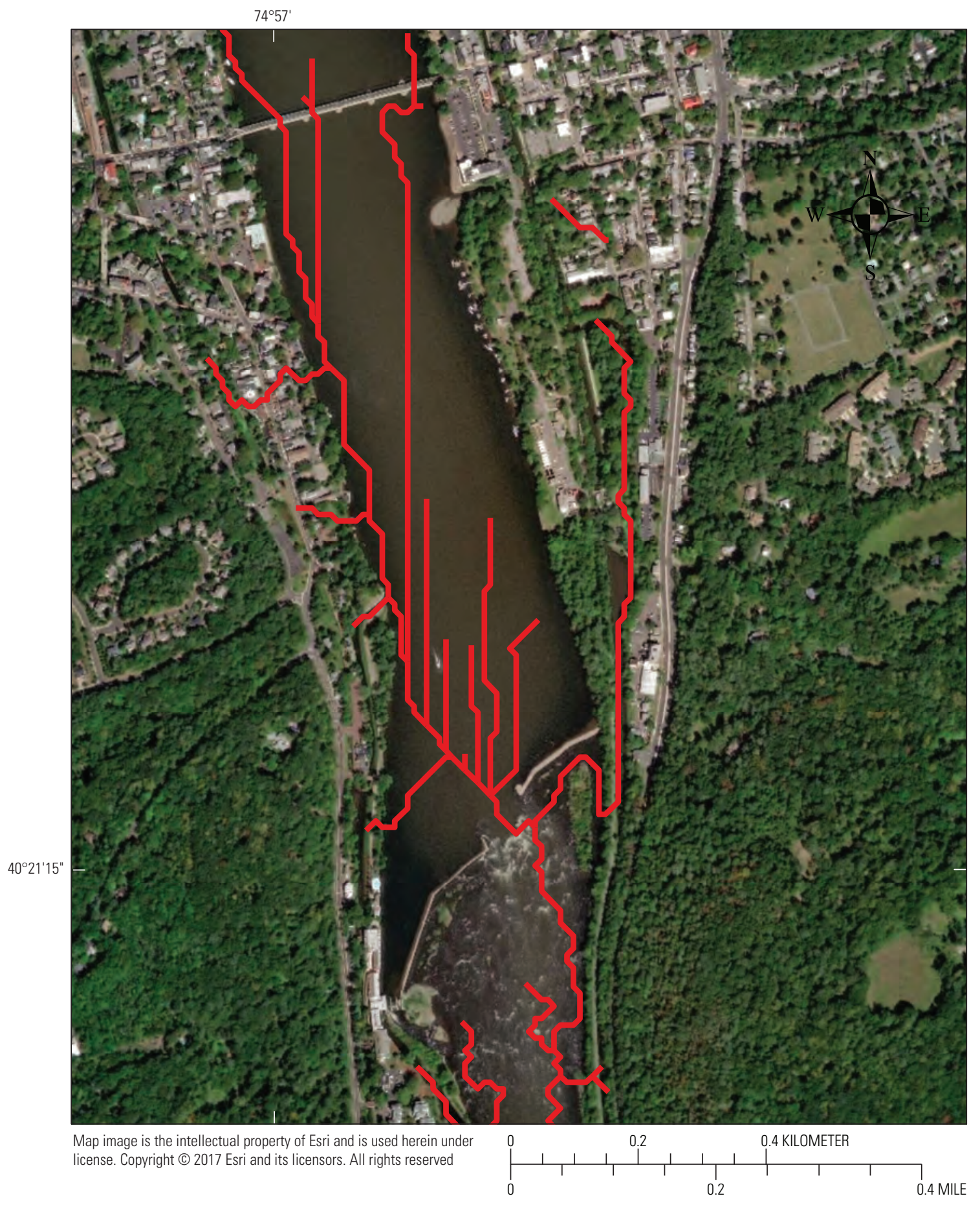

\section{EXPLANATION}

Synthetic flowpaths

0.05 percent of maximum

flow accumulation (MaxFAC)

Figure 5. Trellis patterned synthetic flowpaths for 10-meter resolution Trenton Group at 0.05 percent of the maximum flow accumulation value. 
trellis pattern, lowering the FAC decreases the density and distribution of potentially useful synthetic flowpaths in other river reaches. If the modeler prefers using the smaller FAC, steps can be taken to improve extracted channel delineations, such as burning a trench through the center of the obstruction. In this case, burning a trench through the weir or directing the flowline through the lock located on the left side of this feature will improve results for channel extraction.

\section{Bathymetric Lidar Synthetic Flowpaths at Different Resolutions}

To choose the most useful FACs, choosing the best resolution of lidar DEMs to extract synthetic flowpaths may depend on site conditions that obstruct and alter the primary flow direction detected in the FDR process or conditions such as where low topographic relief makes it difficult for the FDR function to create the flow grid needed to develop the stream definition. The difference in results using different resolutions is clearly shown where an in-channel island obstructs the flow direction at a section of the Trenton Group (fig. 6). West of and upstream from the in-channel island, the synthetic flowpaths extracted from 1-meter resolution geodata using 1 percent of the MaxFAC create a continuous main river channel and additional synthetic flowpaths that depict part of a parallel river channel and canal. To the west side of the island, the synthetic flowpath developed for the main river channel becomes discontinuous until about halfway around the island, where synthetic flowpaths on either side of the island are created and then merge on the east side of the island. Continuing east of the island, the 1-meter resolution lidar BDEM created additional, false channels. In NAIP orthoimagery, these features delineated a canal and a tree line lineament (fig. 6).

In contrast to results extracted from 1-m resolution data, synthetic flowpaths extracted from the 5-m (not shown) and 10-m resolution lidar BDEM represent continuous river channels around the northern side of the in-channel island, but results are discontinuous on the south side for the 1-m resolution. The 1-m resolution FDR shows that grid cells in the area west (upstream) of the in-channel island are multidirectional, which seems to have affected the FAC requirement for developing stream segments and limited the stream segment connectivity (fig. 6). The FDR for the 10-m (and 5-m) resolution lidar BDEM shows dominant east-directed flow.

Synthetic flowpaths created at another section of the Trenton Group using 1-, 5-, and 10-meter resolution lidar BDEMs provide another example of differences for results that seem to be due to site conditions (fig. 7). In this case, the Delaware River flow path is disrupted by an in-channel island at a bend where the river is bordered by a low-relief river terrace. West of the in-channel island, the 1-m resolution lidar BDEM depicts isolated synthetic flowpaths for the east- and southeast-flowing Delaware River until about midsection of the island. These disconnected synthetic flowpaths correspond in position with the continuous synthetic flowpaths created from 5- and 10-m resolution lidar BDEMs. At about the middle of the island, the 1-m resolution synthetic flowpaths on the north and south side merge to represent the main river channel (fig. 7). The 10-m (and 5-m) resolution lidar BDEM depicts the Delaware River as a single river channel on the south side of the island. Similar to results for the site previously described and shown as figure 6 , the 1-m resolution lidar BDEM develops additional isolated synthetic flowpaths not included in the results for the two other lidar BDEM resolutions. In this case, one of the synthetic flowpaths is south of the main river channel in a shallow water body where the FDR indicates a uniform west-directed flow, which is opposed to the general eastward flow direction.

The HR NHDFlowline network Artificial Path of the river shown in figure 7 delineates the river centerline. Synthetic flowpaths derived from the 5-and 10-meter resolution lidar BDEMs cross back-and-forth over the NHDHR Artificial Path and in some areas the synthetic flowpaths and the artificial path are offset about $85 \mathrm{~m}$. A cross-section profile (not shown) indicated the river bottom is almost flat.

The FDR created for the 1-m resolution lidar BDEM developed highly variable flow directions (fig. 7). There are no obvious obstructions to alter the general easterly flow direction and in this case the low-relief river bathymetry identified in the 1-m resolution lidar BDEM is thought to prevent development of a dominant flow direction. Conversely, in the same survey area the FDR for the 10-m (and 5-m) lidar BDEM developed a distinct easterly flow direction (fig. 7). These results show that although the 1-m lidar BDEM delineates some additional synthetic flowpaths, the FAC does not develop connected stream segments and the larger resolution lidar BDEMs are more useful for developing a main river channel. A recommended solution for developing more continuous synthetic flowpaths when the lateral extent of bathymetric/ topobathymetric lidar surveys is limited is to develop better flow accumulations for river systems by including surrounding DEMs (Stanislawski, 2017). Future analyses could include trial runs to assess results using this technique for extending lidar bathymetric synthetic flowlines.

Results for extracting synthetic flowpaths at a river bend in the Hancock Narrows Group show another example of how site conditions can have different effects on FDRs created for different resolutions (fig. 8). In this case, using 0.05 percent of the MaxFAC as the FAC, the 1-m resolution lidar BDEM synthetic flowpath representing the Delaware River channel is discontinuous just north of an in-channel island, but upstream from the island the 1-m resolution lidar BDEM forms a continuous river channel where the 5 - and $10-\mathrm{m}$ resolution lidar BDEMs form trellis patterns (fig. 8). Another difference between results at different resolutions was found at the river terrace located south of the river bend where a tributary identified in the HR NHDFlowline network that is delineated in the 1-m resolution lidar BDEM as a continuous lineament is not completely developed for synthetic flowpaths extracted from 5- and 10-m lidar BDEMs (fig. 8). These differences also are attributed to the FDRs created at different 

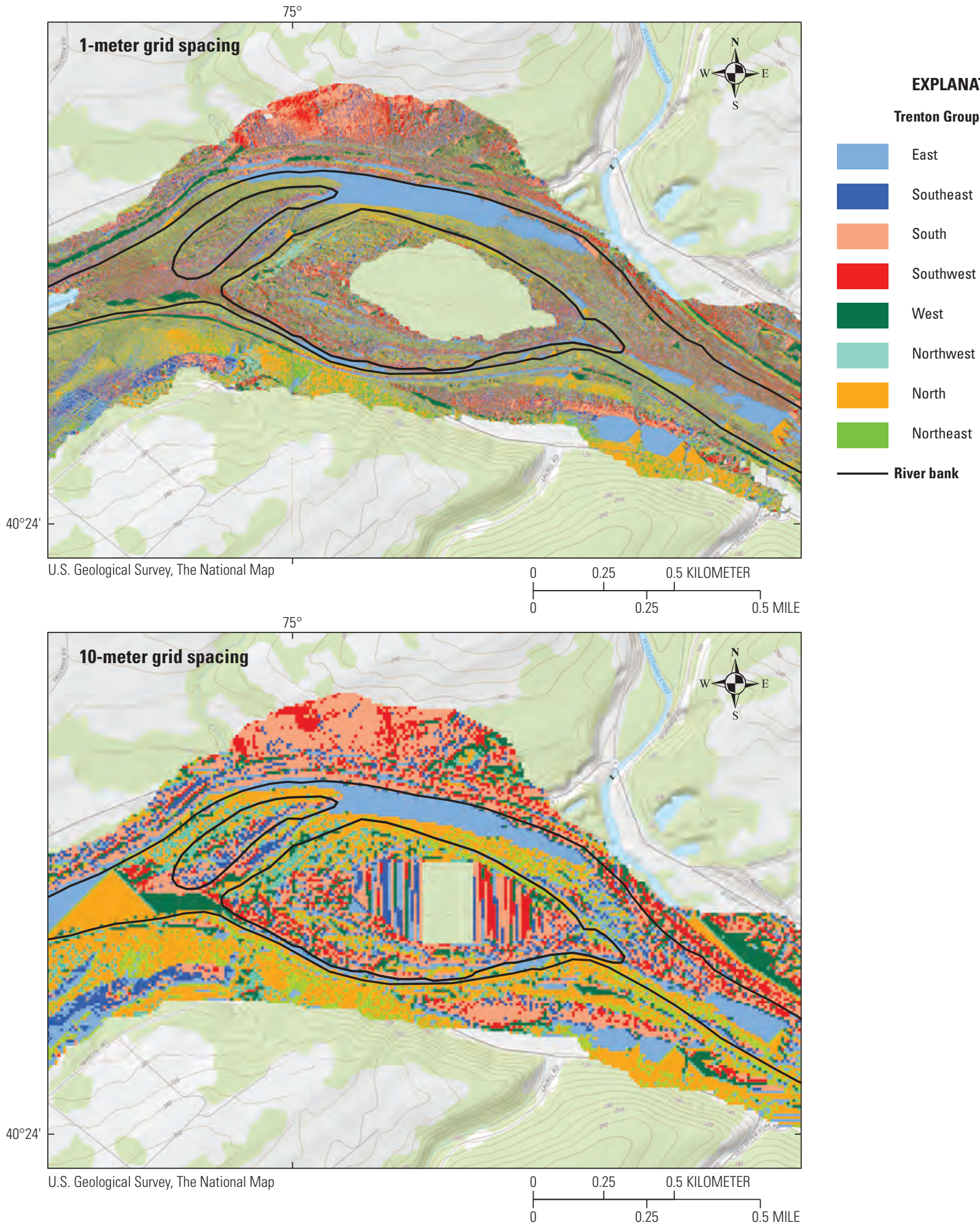

Figure 6. Flow direction grids for 1-meter and 10-meter resolution bathymetric light detection and ranging (lidar) digital elevation models. 

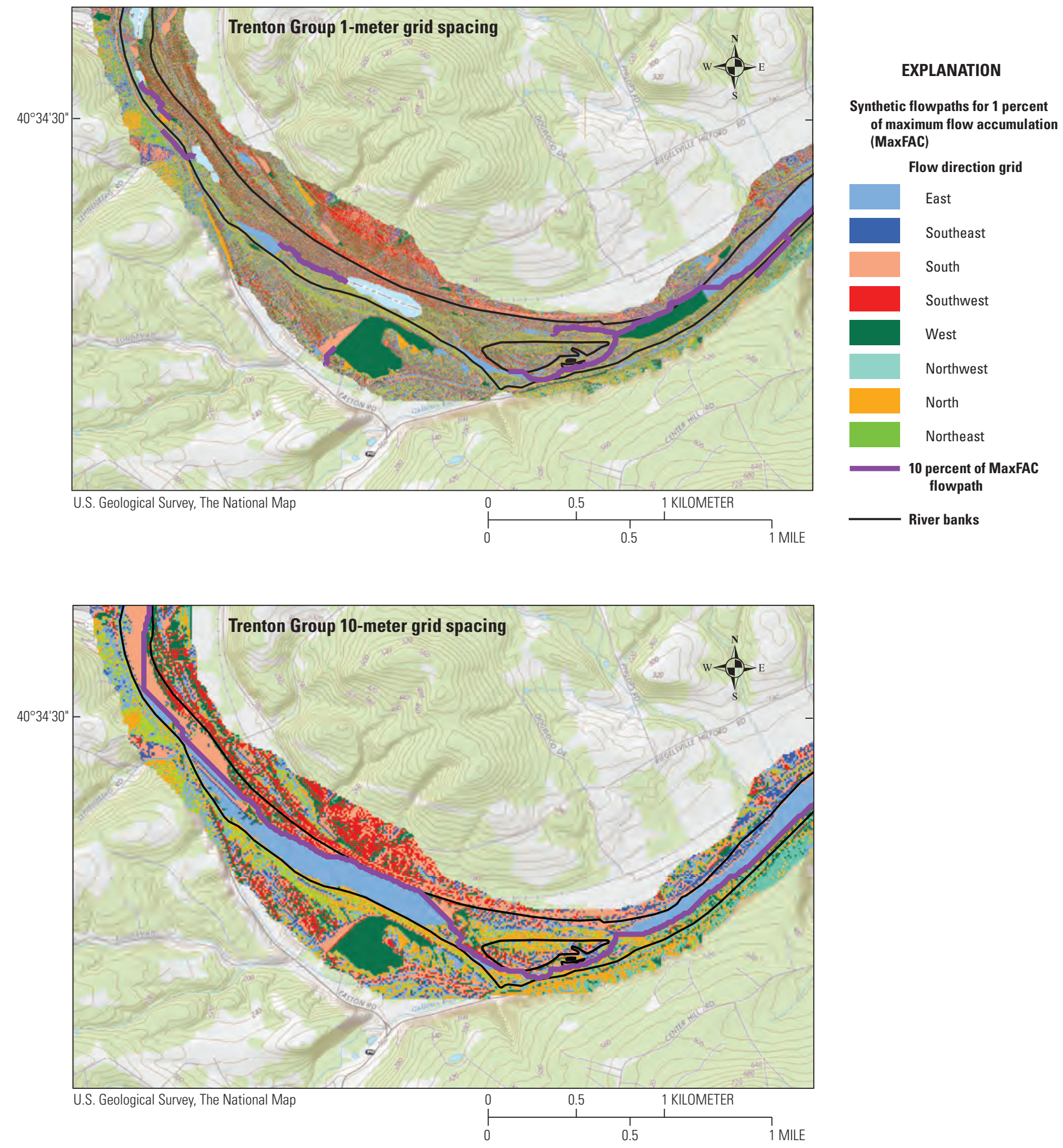

Figure 7. Synthetic flowpaths in flat terrain for Trenton Group at 1-meter and 10-meter resolution bathymetric digital elevation models. 

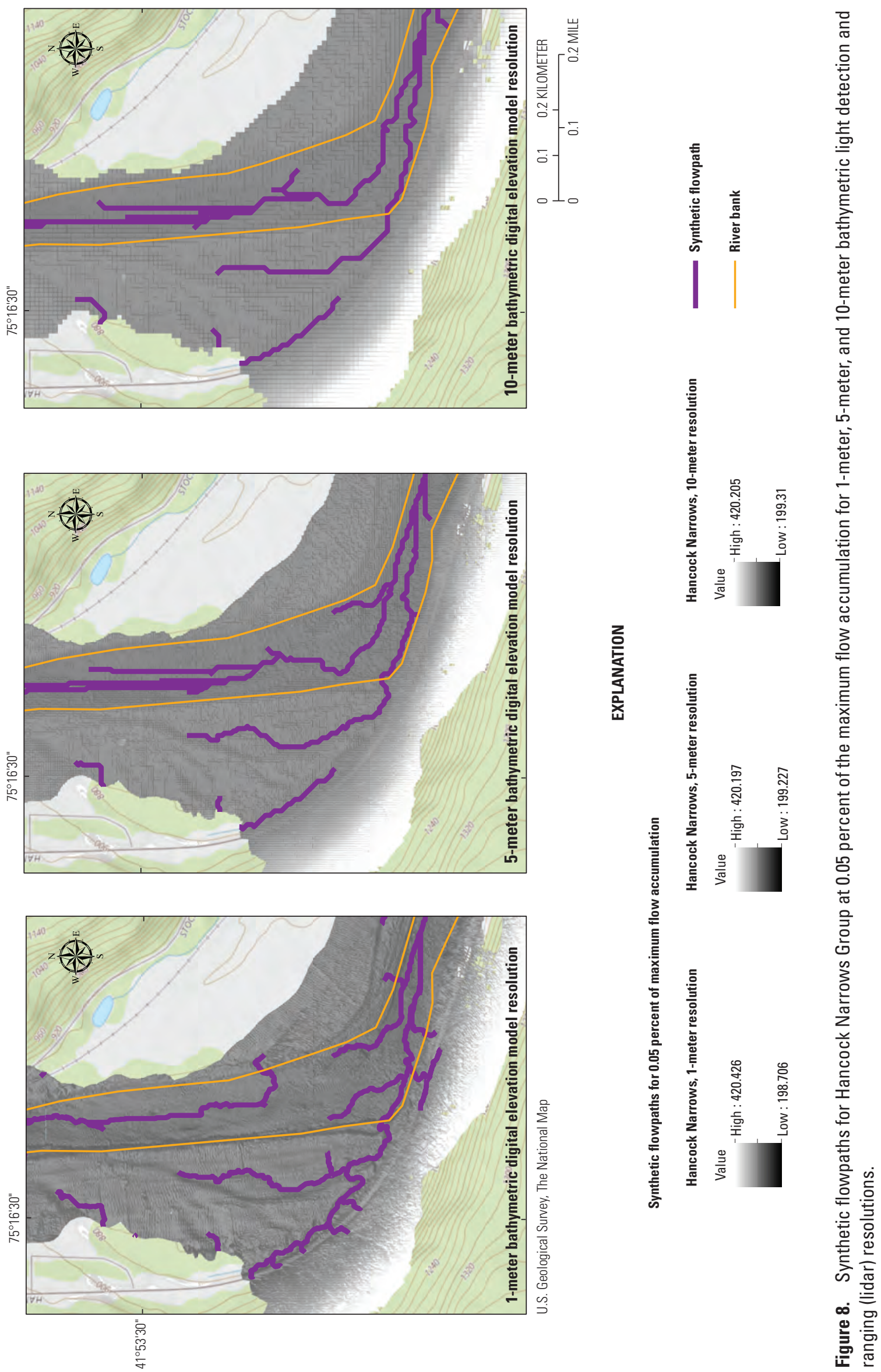

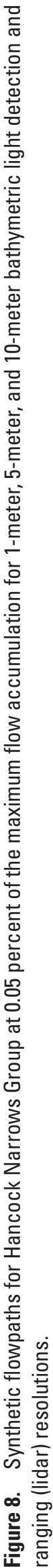

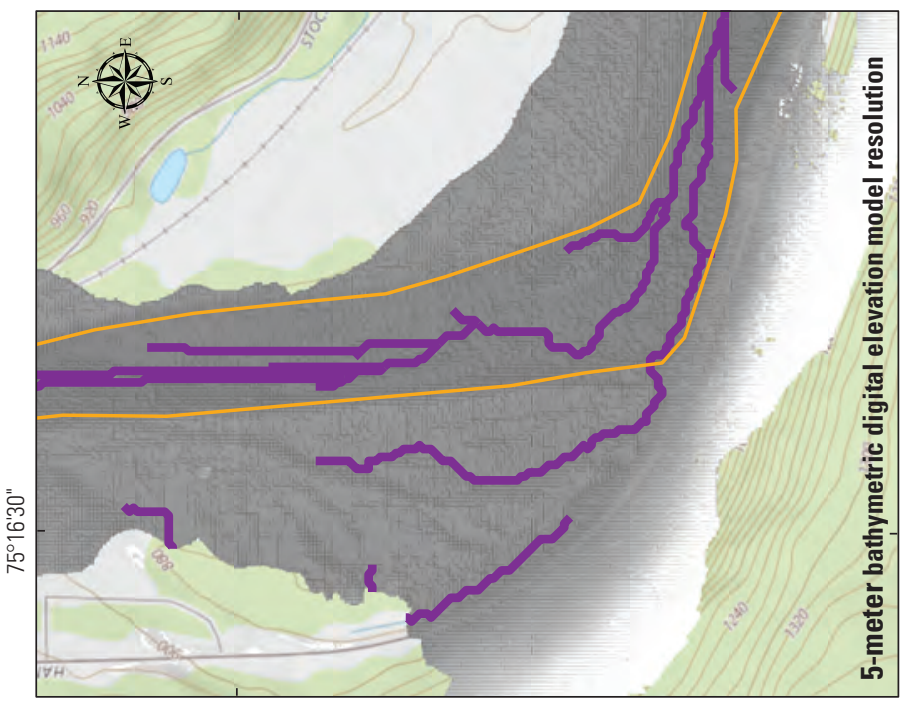

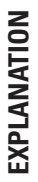

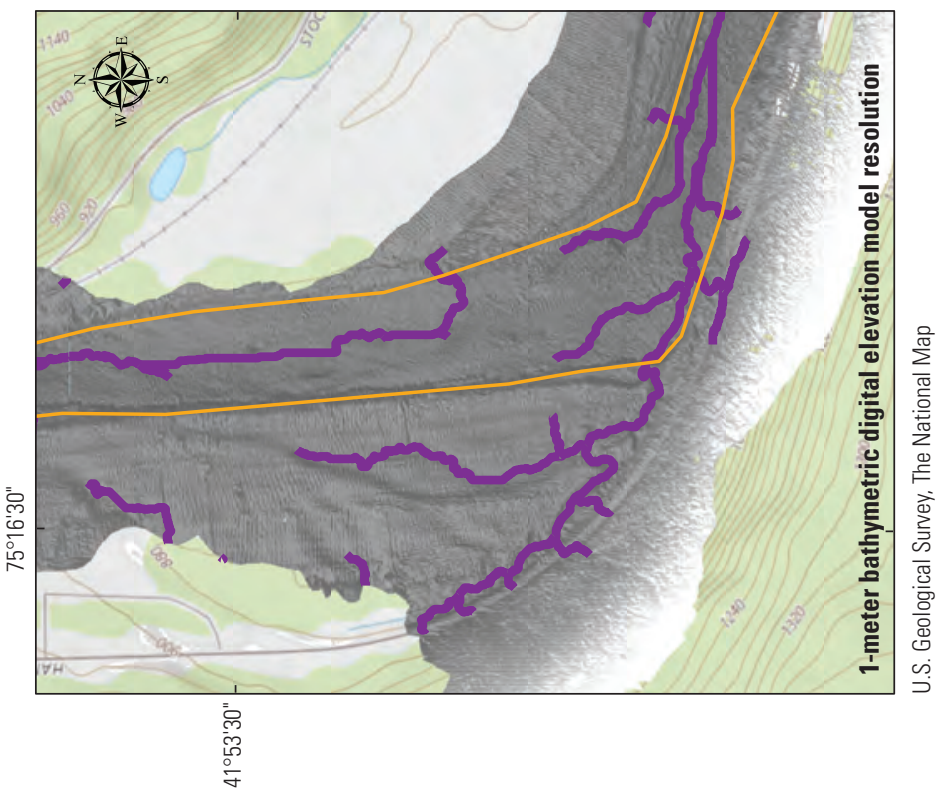


resolutions. South-southeast directed flow was created for 1-m grid cells but in the same area 5 - and 10-m resolution lidar BDEMs created the disconnected tributary lineament. FDRs show south and southwest trending flow directions that would prevent flow accumulation from developing continuous stream segment geometries (fig. 9). Lidar BDEMs at all resolutions created a synthetic flowpath for a long, narrow topographic low adjacent to the river channel.

\section{Lidar Synthetic Flowpaths and National Hydrography Dataset High Resolution Flowline Network Correspondence}

Alignment of lidar BDEM synthetic flowpaths delineating the Delaware River with the HR NHDFlowline network Artificial Path indicates synthetic flowpath extraction using 1 percent and 0.05 percent of the MaxFAC value can provide baseline digital data as a resource for enhancing major river flowpaths in the HR NHDFlowline network. Although the bathymetric survey lidar DEMs do not reach more than a couple of hundred meters landward of the Delaware River banks, overlaying synthetic flowpaths using 0.05 percent of the MaxFAC with NAIP orthoimagery and the HR NHDFlowline network shows places along the Delaware river corridor where synthetic flowpath positions correspond with or connect to the HR NHDFlowline network Artificial Path and stream/ river features that extend upslope of the river banks (fig. 10).

Places such as shown in figure 10 where there is good correspondence with the HR NHDFlowline network feature types indicate that synthetic flowpaths derived at the 0.05-percent MaxFAC value for 5-m resolution data could serve as a baseline for evaluating potential updates to enhance the accuracy, density, and geographic distribution of the HR NHDFlowline network. Additional synthetic flowpaths that do not match up with HR NHD flowlines would need to be validated using NAIP orthoimagery, 3DEP DEMs, or other resources to help decide whether these could be integrated to improve the density, distribution, and connectivity of the HR NHDFlowline network. As an example, U.S. Topo maps show that some of the ESFs that do not connect with or extend HR NHDFlowline network stream/river features occur where V-shaped contour patterns depict either valleys or streams that seem to be connected to the river channel. Synthetic flowpaths connected to these contour patterns could be further evaluated to see if the synthetic flowpaths represent valid stream/river features that could be used to enhance density and connectivity in the HR NHDFlowline network; however, heavily forested slopes, such as those in this study area, can hide the bare earth so that the potential tributaries may not be validated in orthoimagery. Although using 0.05 percent of the MaxFAC for 1-meter resolution lidar bathymetric DEMs for the same area created an almost continuous river channel and some synthetic flowpath features that agreed with HR NHDFlowline network stream/river feature types representing tributaries, many additional drainlines that were not connected to the river channel or the HR NHDFlowline network were extracted, and patterns formed in some reaches of the river trellis. These results again show that there can be tradeoffs for using one resolution instead of another.

\section{Compatibility of Lidar Topobathymetry and 3D Elevation Program Digital Elevation Models}

Compatibility between the Delaware River bathymetric lidar survey model and 3DEP DEMs is assessed by evaluating profiles across bankslope to river bed transitions depicted in the contoured Delaware River lidar BDEM, and difference analyses that reveal correspondence and some differences. Using the Hancock Narrows Group as an example, differences between the lidar BDEM and 3DEP DEMs are concentrated on the outside of river bends and range between 0 and $2 \mathrm{~m}$.

Cross-section profiles that are created from the contoured bathymetric lidar DEM and depict bank slope to river bottom elevations show that the lidar BDEM creates seamless boundaries by presenting smooth elevation transitions from moderately and steeply sloping river banks, through the topographicbathymetric interface, and to the river channel bottom without gaps (fig. 11). The uninterrupted slope surfaces indicate the lidar survey sensor system and processing techniques used to collect and develop the Delaware River bathymetry and topobathymetric components of the Delaware River corridor survey are able to successfully merge the two (green and nearinfrared) lidar waveforms.

Although the results for the bathymetric/topobathymetric lidar sensor system create a seamless boundary for the merged bathymetric-topographic elevation model, this does not ensure agreement between the lidar BDEM and 3DEP DEMs. To assess agreement between the Delaware River lidar survey DEMs and 3DEP DEM raster datasets, the 3DEP DEM was extracted using the footprint of the lidar survey tiles for the Hancock Narrows Group and the resulting 3DEP DEM raster dataset was differenced with the Hancock Narrows Group. Differences between the lidar survey elevations and 3DEP DEMs were contoured at 2-m intervals and these results were evaluated for variability between the two model types (fig. 12). Contours for 0 -m differences line both river banks and in general, there is good agreement. In contrast, other resulting difference contours for this comparison show dense contour patterns parallel to the river bank and extending upslope from the shoreline that correspond to a smooth elevation transition up the steep river banks.

Using the sum of difference-contour lengths for a subset of the Hancock Narrows Group in this area, most of the differences between the bathymetric lidar survey results and 3DEP DEMs are 0 to $6 \mathrm{~m}$. There were $0-\mathrm{m}$ difference contours for about 25 percent of the comparison, 2-m difference contours for another 30 percent, and 4-m difference contours for 19 percent. In the same region there are differences of 4 or $6 \mathrm{~m}$ that account for another 25 percent of the comparison. The distribution of comparison results is similar to that for analysis 
1-meter resolution flow direction grid
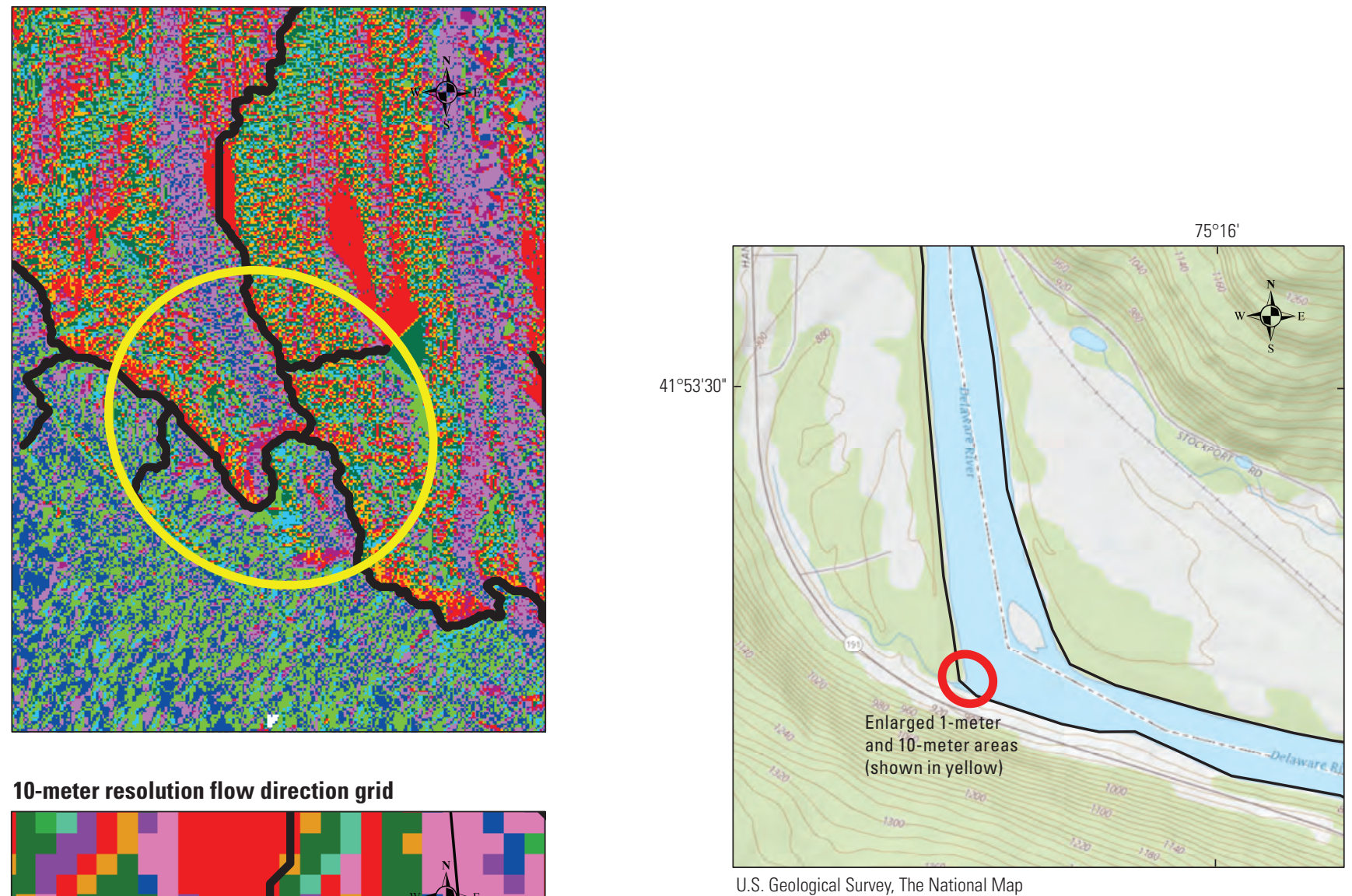

\section{0-meter resolution flow direction grid}

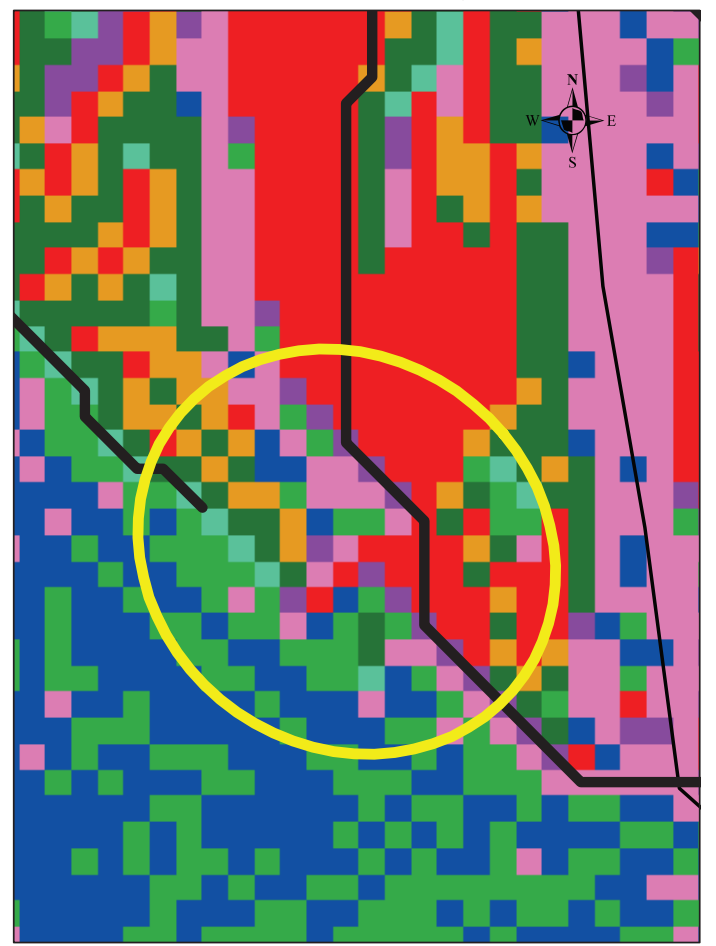

$41^{\circ} 53^{\prime} 30^{\prime \prime}$

\section{EXPLANATION}

D8 flow direction grid

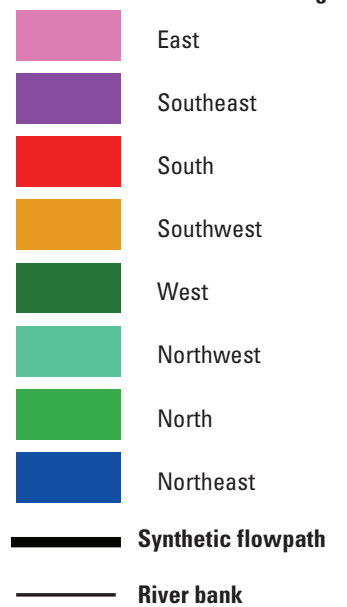

U.S. Geological Survey, The National Map

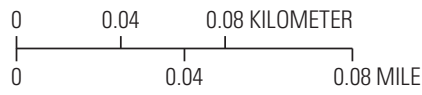

River bank

Figure 9. Hancock Narrows Group D8 flow direction grid for 1-meter and 10-meter bathymetric light detection and ranging (lidar) digital elevation model resolution. 


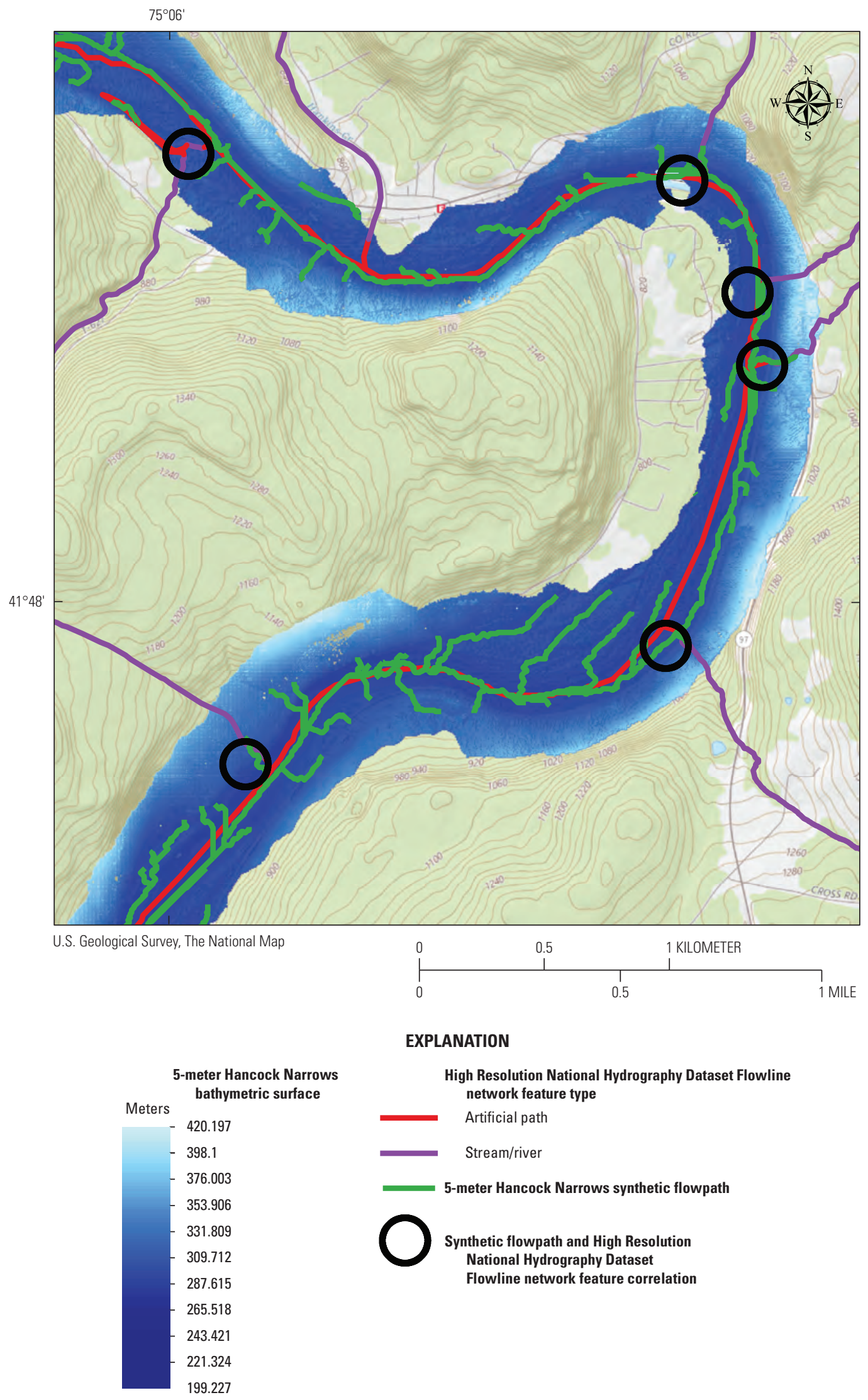

Figure 10. Correspondence between bathymetric light detection and ranging (lidar) synthetic flowpaths and the High Resolution National Hydrography Dataset Flowline network. 


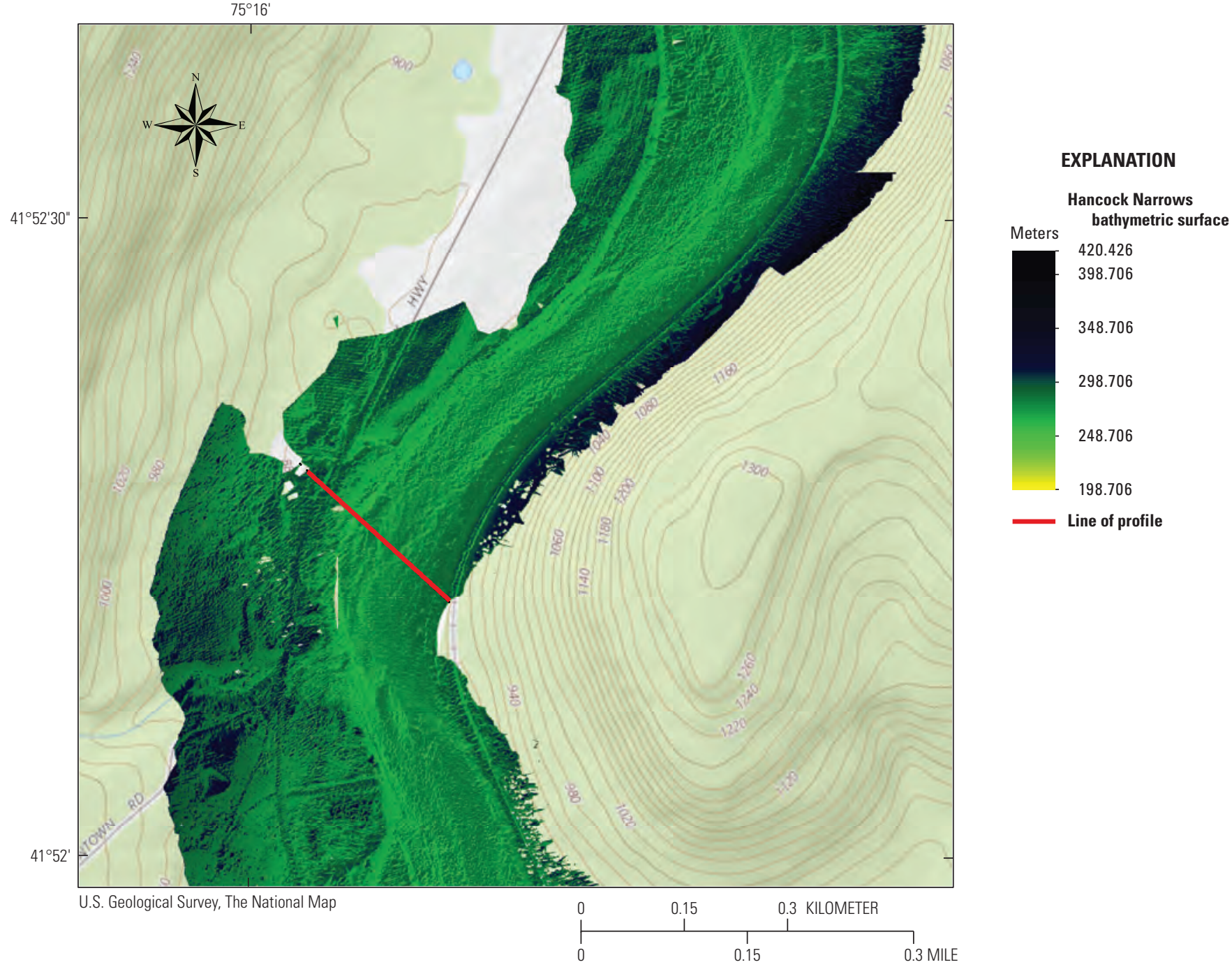

Delaware River cross-section profile

Hancock Narrows Group, 1-meter resolution

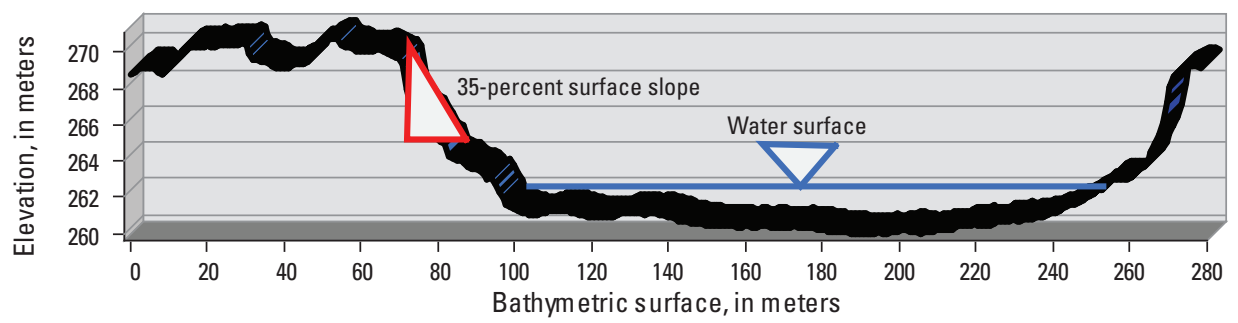

Figure 11. Bank slope to river channel bottom without gaps derived from light detection and ranging (lidar) bathymetric/ topobathymetric digital elevation model. 

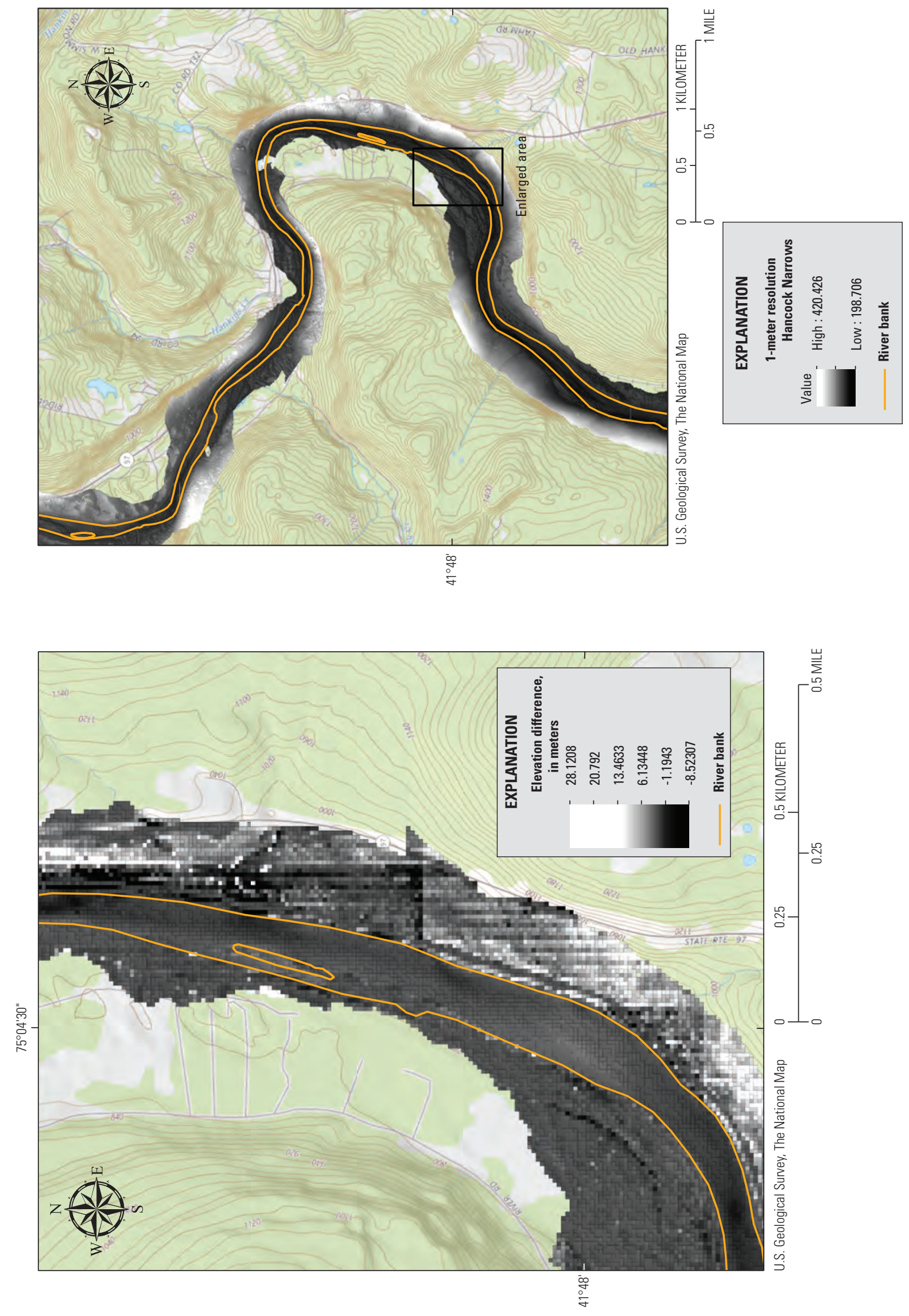

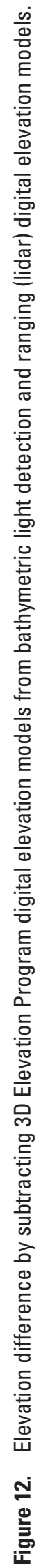


of the entire Hancock Narrows Group. When all of the Hancock Narrows Group is evaluated for correspondence with 3DEP DEMs, there are no differences for about 33 percent of compared elevations, 2-m differences for about 30 percent, and 4-m differences for about 15 percent. For the subset of the Hancock Narrows Group, the largest differences between the two model types are concentrated as two clusters of grouped outliers forming at the edge of the lidar survey tiles on the north and south side of a river reach (not shown). Large differences also occur as clusters of outliers in the steep, heavily treed terrain upslope from the river bank or at the edges of the lidar survey.

Calculated elevation differences farther upslope of the river banks indicate there are issues that may need to be resolved for new lidar topobathymetric geodata to seamlessly merge with 3DEP DEMs. As an example, a comparison of elevation profiles across the two model datasets in an area where the lidar BDEM covers steep, forested valley slopes shows that the upper and lower elevations for the two profiles are the same, but the contour patterns between the two profiles are different (fig. 13). Also, the topobathymetric lidar BDEM data created a ridge-valley type profile where the 3DEP DEM elevation contours reflect a smoothly sloping terrain. Overlaying orthoimagery and the lidar BDEM elevation contours showed the lidar BDEM delineates tree tops or gaps between trees instead of bare earth topography.

The lidar data provided for this analysis were not classified, and where the river survey extends to include terrain elevations upslope from the river, the data were not processed to provide a bare earth surface terrain. Classification of EAARL-B lidar BDEMs and other bathymetric or topobathymetric lidar survey products to identify bare earth, structures, vegetation, and water features will help to understand and resolve the described differences. Otherwise, the 3DEP DEM provides the superior source.

\section{Discussion}

Overlaying results for synthetic flowpaths extracted from bathymetric lidar models with the HR NHDFlowline network, NAIP orthoimagery, and USGS Topo maps shows places where synthetic flowpath delineations agree with the HR NHDFlowline network and where valid additional synthetic flowpaths may enhance density, distribution, and connectivity of the HR NHDFlowline network. Synthetic flowpaths are not categorized as perennial, intermittent, or ephemeral stream/ river feature types though for the Delaware River, stream/river features proximal to a main river channel are expected to be perennial.

At all resolutions and for all Delaware River survey groups, using 1 percent of the MaxFAC consistently developed synthetic flowpaths delineating the main river channel. Overlaying synthetic flowpaths with NAIP orthoimagery and 3DEP DEMs shows that these synthetic flowpaths often delineate river thalwegs. In the HR NHDFlowline network, the Delaware River is an Artificial Path feature type, and in some river reaches, the HR NHDFlowline network Artificial Path is offset from the river channel delineated in NAIP orthoimagery. The Artificial Path feature type is intrinsic to the NHD, providing delineation of major rivers and other HR NHD flowlines $12.2 \mathrm{~m}$ wide or larger. However, developing a new feature class or type to acquire and maintain channel thalweg data could provide a geospatial database for 3-dimensional river channel geodata that could supplement HR NHDFlowline network Artificial Path feature types to provide river channel geometries important for accurate analyses and modeling.

Synthetic flowpaths created from several trial runs using both ArcHydro and TauDEM software applications were similar, although using the D-Infinity tool sometimes developed streamlines with curvature that better resembled natural stream geometry. Both tools developed trellis patterns for areas where the natural river flow direction was obstructed. An evaluation of results from using both tools in a subsample from lidar DEMs for locations with different site conditions can provide a more quantitative comparison between ArcHydro and TauDEM stream extraction techniques than was done in this study.

Based on results for the Delaware River lidar survey lidar BDEMs, using 0.05 of the MaxFAC created the best results for evaluating benefits or issues for using bathymetric lidar synthetic flowpaths as a source for enhancing the density, distribution, and (or) connectivity of the HR NHDFlowline network stream/river feature type. In some areas, apparently valid synthetic flowpaths that are not included in the HR NHDFlowline network could be integrated to enhance the density, distribution, and/or connectivity of the HR NHDFlowline network. Valid synthetic flowpaths may not be in the HR NHD geodata because requirements for including data at the 1:24,000 map scale precluded these stream/river features, or because the hydrographic features were inadvertently or purposefully omitted. Another reason for omission may be that geologic and (or) hydrologic site conditions may have changed surface-water feature patterns over time.

Depending on lidar DEM resolutions and (or) FAC values, uniformly filling low points or sinks in the bathymetric surface using the default Fill Sink function created realistic and continuous synthetic flowpaths for the dendritic river system; initial tests using different Fill Sink depth values did not seem to improve results. Reconditioning to align extracted channels with the flowline network was not required and hydro-enforcement was not used. However, in addition to the Fill Sinks function, tools or techniques to improve disconnected or discontinuous synthetic flowpaths should be further tested for providing improved results without altering the natural surface-water system geometry in flat areas or areas where flow is interrupted.

Understanding site conditions that can cause poor synthetic flowpath extraction is important for developing successful survey plans. These site conditions need to be considered when selecting appropriate geodata resolutions or FACs and when choosing techniques or software applications 

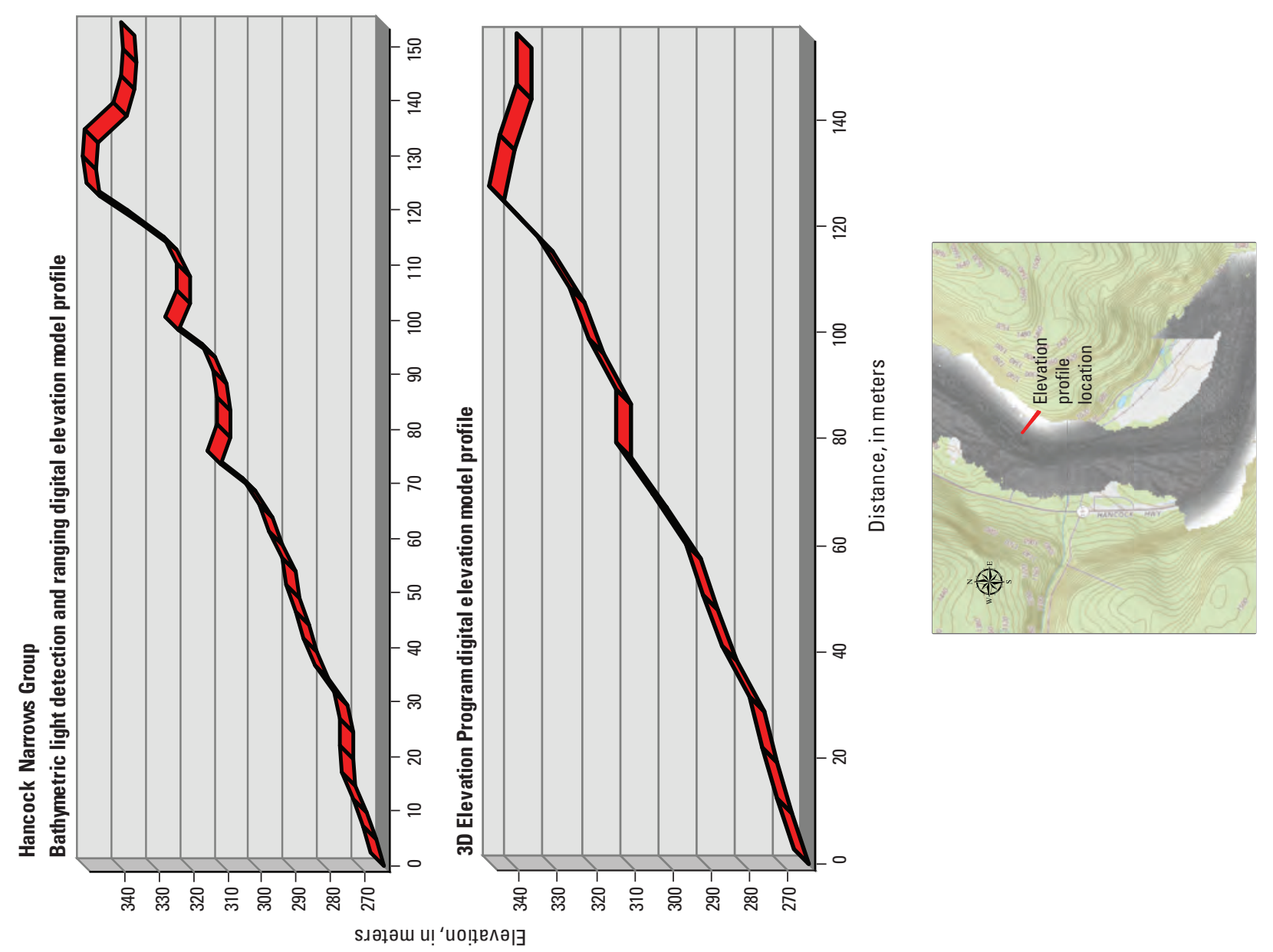

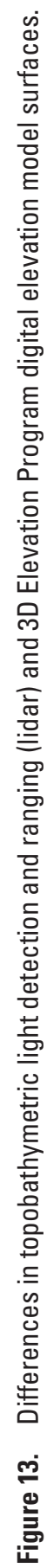
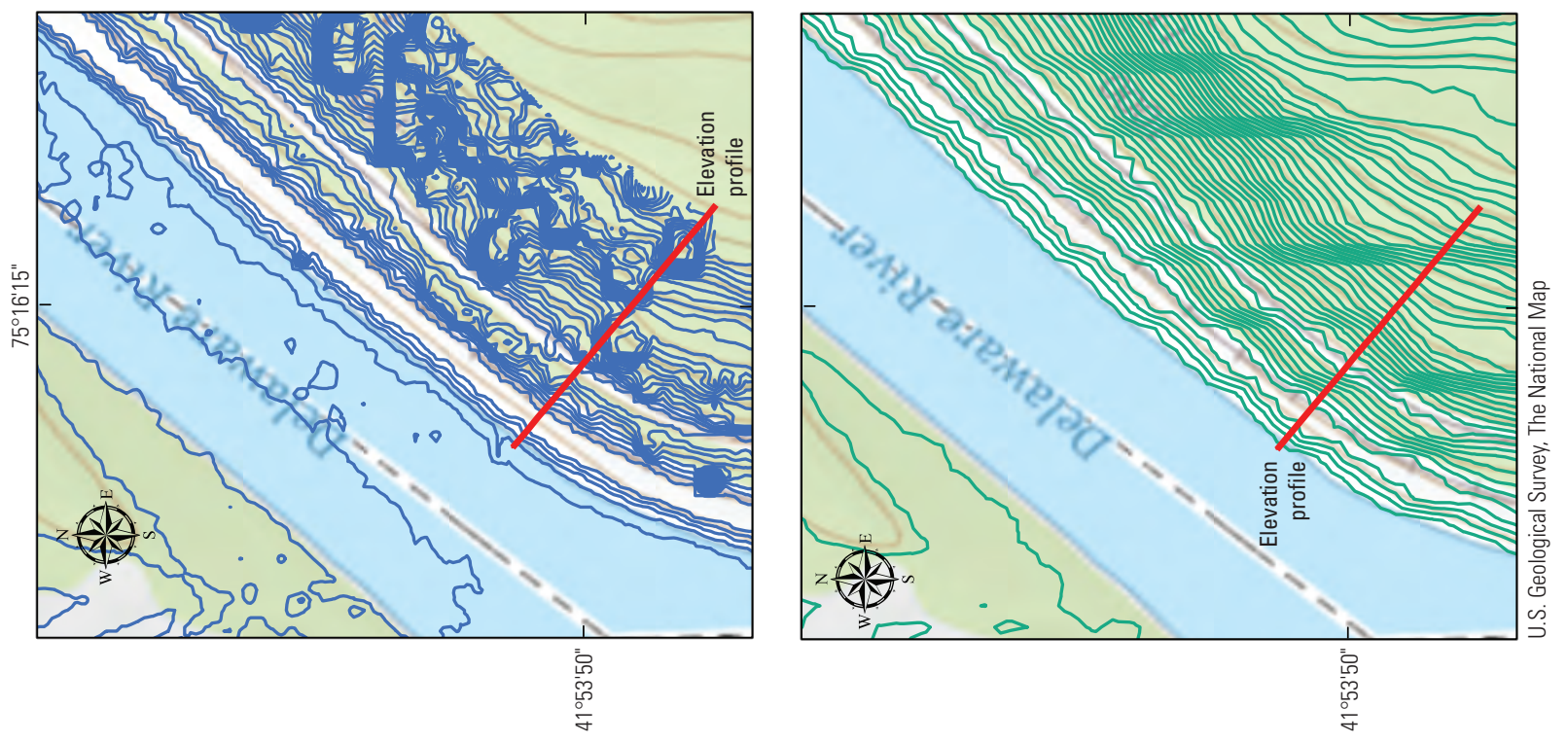
to overcome obstacles for successful extraction of synthetic flowpaths. Changes in geomorphology that control river channel geometries can present natural limitations for developing accurate representations of channel configurations. At some locations along the Delaware River corridor, synthetic flowpaths depicting the potential river thalweg did not correlate with the HR NHDFlowline network Artificial Path for the river, and the FDR developed stream segments for stream/ rivers or canals running parallel to the main channel. At other sites, neither the Artificial Path nor the extracted river channel synthetic flowpath correspond with the deepest part of the main river channel potentially representing the river thalweg. For both cases, the lack of correspondence could be expected because river footprints can be modified by storms or changes in flow volumes that cause changes in river bedform stability.

Within the river and along river banks, in NAIP imagery neither submerged aquatic nor land-surface vegetation that might impede or diminish the quality of bathymetric or topographic laser waveform returns were seen; however, in some areas, tree lines just landward of river banks were sometimes interpreted as stream/river lineaments, or a ring of trees surrounding an exposed land surface was developed as an elevation data polygon surrounding a depression. The lidar topobathymetric survey and the 3DEP 10-m lidar DEMs depicting bare earth elevations merged well in the areas immediately adjacent to river banks. Notwithstanding, the lidar topobathymetric survey data were not classified and upslope from the river banks the topographic elevations seem to identify tree tops or other ground cover. Without classification of the lidar topobathymetric data, 3DEP DEMs provide better topographic elevations.

Site conditions such as flat terrain, pool riffles, or inchannel islands affect the FDR application and cause apparent altered flow directions that generate isolated, disconnected, or invalid synthetic flowpaths, which can mean that the right FAC for creating useful synthetic flowpaths in some parts of a river reach may not provide good results in other river reaches. Altered flow that happens in areas upstream from human-made obstructions such as weirs also can prevent developing useful flow direction grids. Problems extracting synthetic flowpaths where flow is altered, or in areas of low-relief topography and bathymetry indicate software tools could be modified or developed to create improved FDRs for where these site conditions exist.

The lidar BDEMs created from bathymetric and topobathymetric lidar DEMs for the Delaware River provide examples for how lidar BDEMs could be a viable and beneficial data source for the HR NHDFlowline network. The results of this analysis are specific to the Delaware River corridor where the water is clear and the river flowpath is usually confined in a steep-walled river valley. Where surveyed, the river is not braided but in many sections in-channel islands or rough river bottom surfaces altered the flow direction, preventing synthetic flowpaths from developing. Poor flow direction grids also developed where the river corridor includes naturally flat river terraces or flood plain terrain. Synthetic flowpath extraction from lidar bathymetry and topobathymetry for rivers flowing in unconfined conditions would benefit from improved techniques to better define flow directions.

This investigation focused on evaluating synthetic flowpaths extracted from bathymetric lidar DEMs as a source for enhancing the HR NHDFlowline network. Although results support this approach for enhancing the HR NHDFlowline network, further investigation is needed to better determine criteria for selecting appropriate survey sites and for understanding software routine limitations for extracting synthetic flowpaths from lidar bathymetry. The lateral extent of the Delaware River bathymetric lidar survey pre-empted analysis of catchments or watersheds for comparison with the HR NHD WBD HUCs. To assess this approach for enhancing the delineation of HR NHD catchments or watersheds, a project to prototype development of catchments or watersheds created by connecting lidar synthetic flowpaths with lineaments analogous to synthetic flowpaths that could be extracted from 3DEP DEMs is recommended.

Results of the investigation indicate lidar synthetic flowpaths can help provide the following:

- Enhanced delineation of HR NHDFlowline network features types and geometries.

- Improved connectivity within the HR NHDFlowline network.

- Slope to river bottom transitions without gaps for coastal zone and inland surface-water features.

- River channel thalweg delineations as a new geospatial feature to supplement HR NHDFlowline network Artificial Paths.

- The third-dimension need to develop 3-dimensional river channel models where water clarity and depth permit.

- Support to the NGP long term goal to better integrate elevation and hydrography and to provide 3-dimensional representations of natural and constructed features.

The NGP is still building a foundation of knowledge regarding use of lidar hydrography and is not committed to formalizing use of this technology. The level of effort for using synthetic flowpaths as a data source would depend on needed resources and requirements to improve the distribution, density, and (or) connectivity of the HR NHDFlowline network.

As a next step in developing an understanding of the beneficial use of lidar hydrography, bathymetric lidar DEMs for different river geometries under variable site conditions is recommended. This analysis would help to determine the appropriate use of pre-extraction reconditioning tools and to identify river systems as candidates for bathymetric lidar surveys. Inland to coastal bathymetric lidar surveys are increasingly being considered for mapping surface-water 
features. Communications or outreach to USGS Water Science Centers and other entities acquiring bathymetry could also provide survey systems and information about available data to help assess appropriate targets or site conditions that hinder development of valid hydrography. Another recommendation is to develop a database for river channel bathymetry to collect lidar BDEMs that include major river thalwegs as a new HR NHDFlowline network feature type. Developing this data source will help to provide accurate hydrographic data for HR NHDFlowline networks s and water bodies that are fundamental to hydrologic and hydraulic analyses and modeling used in water resource management and other fields such as environmental or aquatic habitat protection programs or flood plain management.

\section{Summary}

Extracted synthetic flowpaths (ESFs) for the Delaware River Survey were compared with the High Resolution National Hydrography Dataset (HR NHD) Flowline network to see how these geospatial data could be used to update the hydrographic geospatial dataset. Main river channel and stream/river features were created using different flow accumulation threshold values (the number of cells or area needed to create an ESF) for 1-, 5-, and 10-meter (m) resolution bathymetric/topobathymetric light detection and ranging (lidar) digital elevation models (DEMs) to determine the ESF results that best correspond with the HR NHDFlowline network and results that created additional stream/river feature types that could be used to improve the density, distribution, or connectivity in the HR NHDFlowline network. ESFs depicting additional stream/river features were compared with National Agriculture Imagery Program orthoimagery, U.S. Topo Maps, and 3D Elevation Program DEMs to evaluate whether the ESFs represented real flowpaths or if these lineaments delineated other linear features such as canals, tree lines, roads, or linear topographic depressions.

The total length of the Delaware River is around 320 kilometers. From north to south, the lidar bathymetry/topobathymetry survey data includes the Hancock Narrows, Middle River, and Trenton Group(s). Using 1 percent of the MaxFAC value as the FAC for grid cells at 1-, 5-, and 10-meter resolution created a combined length of 223 to 283 kilometers of ESFs that correspond to the main river channel and potentially represent the river thalweg. These results suggest a potential for enhancing the HR NHDFlowline network, perhaps as a supplemental data source, by delineating the river thalweg in places where the Delaware River area is depicted as an Artificial Path feature type in the HR NHDFlowline network. Using 0.05 percent of the maximum flow accumulation at the 1-, 5-, and 10-m resolutions extracted a total of 744 to 1,317 kilometers of ESFs, with 780 kilometers representing the main river channel and additional synthetic flowpaths. At each resolution, decreasing the FAC from 1 percent to 0.05 percent increased the resulting length of synthetic flowlines by a factor of 3 to 4 for the Hancock Narrows and Trenton Group(s), and by a factor of 5 for the Middle River Group. The cause for the larger difference for the Middle River Group is not known. One explanation may be that the Hancock Narrows and Trenton Group(s) are continuous, but the Middle River Group is discontinous and the lower FAC was needed to successfully develop denser, connected ESFs. We found that using FAC values greater than 0.15 percent of the MaxFAC, results were similar to those for using 1 percent. Using less than 0.05 percent of the MaxFAC created significantly more ESFs that were not useful for this analysis.

Calculating the area covered by ESFs based on the DEM resolution and FAC values, for all survey groups and for all three DEM resolutions, changing the FAC from 1 to 0.05 percent of the MaxFAC consistently increased the area covered by a factor of 20. For the Hancock Narrows and Middle River Group(s), the area for an ESF created using the 1 and 0.05 percent MaxFAC values for 1-m resolution geodata was about one-half the area covered by an ESF created using 10-m resolution bathymetric/topobathymetric lidar DEMs. Using the 1 and 0.05 percent MaxFAC values for the Trenton Group, the 1-m resolution ESF covered about one-quarter the area covered by the 10-m resolution ESF. Understanding the difference for results can help to plan and refine ESF projects based on the area of interest.

The Delaware River is a dendritic drainage system where the river channel is often cradled by steep-sided valley walls. Based on the results of this analysis, site conditions for the Delaware River corridor did not affect the quality of lidar bathymetry survey data. However, for some river reaches in-channel landforms obstruct flow, and at other places within the Delaware River corridor low-relief topographic or bathymetric surfaces impede software tool derivation of the flow direction. For these conditions the software flow direction tool did not calculate a primary flowpath for the river channel. The effect of these site conditions on synthetic flowpath extraction depended on the lidar DEM resolution. We found that synthetic flowpaths extracted from 1-m resolution lidar DEMs exhibited more varied flow directions around in-channel landforms than ESFs extracted from 5- or 10-m resolution lidar DEMs. As a result the 1-m resolution DEM created some isolated or discontinuous ESF segments where the 5- and 10-m DEMs developed more continuous flowpaths adjacent to the in-channel island. Upstream of the in-channel landform ESFs delineating a potential river thalweg were extracted from the 1-m resolution DEM. However, in the same area the software tool solved for the flow direction by flattening the bathymetric surface which resulted in parallel trellis-patterned ESFs for the river bed in the 5- and 10-m resolution DEMs. Under different site conditions at an abandoned, low-relief river flood plain the flow direction grid for the 1-m resolution DEM developed a continuous ESF corresponding to a HR NHD stream/river but the larger resolution lidar DEMs created isolated or disconnected ESFs. These two examples are representative of results for similar site conditions in other reaches of the Delaware 
River and indicate that using basic terrain preprocessing tools, a) 1-m resolution lidar DEMs were not as good at developing ESFs around in-channel obstructions as the coarser resolution DEMs, and b) 1-m resolution lidar DEMs may provide more continuous ESFs in low-relief areas than the 5- and 10-m resolution lidar DEMs.

Synthetic flowpaths extracted using 0.05 percent of the MaxFAC provide ESFs that best correspond to the HR NHDFlowline network and that provide additional stream/river feature types which could enhance the HR NHDFlowline network with a minimal amount of effort required for revisions to existing HR NHDFlowline network geometries. With the caveat that results are affected by site conditions, we suggest that the community of users could test this FAC value as a starting place for developing ESFs from DEMs to evaluate benefits for using ESFs to enhance the HR NHDFlowline network. In order to extend ESFs into areas where the HR NHDFlowline network is sparse, we also suggest prototype testing to extract synthetic flowpaths from bathymetric/topobathymetric lidar DEMs merged with 3DEP DEMs. Moreover, extending the ESFs could be useful for developing HR NHD catchments and watersheds important in water resource analysis and modeling.

\section{References}

American Society for Photogrammetry and Remote Sensing, 2014, ASPRS lidar guidelines-Horizontal accuracy reporting: 63 p., accessed September 4, 2014, at http://www. asprs.org/a/society/committees/standards/Horizontal_Accuracy_Reporting_for_Lidar_Data.pdf.

Bonisteel, J.M., Nayegandhi, A., Wright, C.W., Brock, J.C., and Nagle, D.B., 2009, Experimental Advanced Airborne Research Lidar (EAARL) data processing manual: U.S. Geological Survey Open-File Report 2009-1078, 38 p.

Carlisle, D.M., and Woodside, M.D., 2013, Ecological health in the Nation's streams: U.S. Geological Survey Fact Sheet 2013-3033, 6 p., accessed February 4, 2017, at https://permanent.access.gpo.gov/gpo41741/fs2013-3033.pdf.

Colson, T.P., Gregory, J.D., Mitasova, H., and Nelson, S.A.C., 2006, Comparison of stream extraction models using LIDAR DEMs, in AWRA Spring Specialty Conference, Houston, Texas, May 8-10, 2006, Proceedings: Middleburg, Virginia, Geographic Information Systems and Water Resources IV, American Water Resources Association, accessed May 5, 2016, at https://files.nc.gov/ncdeq/ Water\%20Quality/Surface\%20Water\%20Protection/PDU/ Headwater\%20Streams/ColsonMay2006ComparisonstreamextractionmethodsProcAWRAGISconf.pdf.
Delaware River Basin Commission, 2013, Administrative manual-Part III water quality regulations: 147 p., accessed October 5, 2016, at https://www.epa.gov/sites/production/ files/2014-12/documents/nj-drbc-wqs.pdf.

Delaware River Basin Commission, 2014, Basin information, national wild and scenic rivers, accessed October 6, 2017, at http://www.nj.gov/drbc/library/images/wild_scenic.jpg.

Djokic, Dean, 2008, Comprehensive terrain preprocessing using Arc Hydro tools: Esri, accessed August 16, 2016, at http://www.arcgis.com/home/item.html?id=41c96fadd2bf49 ff8851002042c0495f.

Esri, 2011, Arc Hydro Tools - Tutorial, Version 2-October 2011: Esri, 189 p., accessed October 2015 at http://downloads.esri.com/archydro/archydro/tutorial/doc/arc $\% 20$ hydro\%20tools $\% 202.0 \% 20-\% 20$ tutorial.pdf.

Esri, 2013, Overview of Arc Hydro terrain preprocessing workflows: Esri, 13 p., accessed March 13, 2016, at http:// downloads.esri.com/archydro/archydro/doc/overview\%20 of $\% 20$ arc $\% 20$ hydro $\% 20$ terrain $\% 20$ preprocessing $\% 20$ workflows.pdf.

Esri, 2014, Arc Hydro-GIS for water resources: Esri, 4 p., accessed August 10, 2016, at https://www.esri.de/ /media/ esri-germany-group/common/files/news/arc-hydro-gis-forwater-resources.pdf.

Esri, 2015, World imagery: National Agricultural Imagery Program, ArcGIS ${ }^{\circledR}$ Online base map software, accessed August 10, 2016, at https:/www.arcgis.com/home/item.html?id=10 df2279f9684e4a9f6a7f08febac2a9.

Federal Geographic Data Committee, 1998, Content standard for digital geospatial metadata (revised June 1998): Washington, D.C., Federal Geographic Data Committee, FGDCSTD-001-1998, 90 p., accessed January 14, 2011, at https:// www.fgdc.gov/standards/projects/metadata/base-metadata/ v2_0698.pdf.

Feurer, Denis, Bailly, Jean-Stéphane, Puech, Christian, Le Coarer, Yann, and Viau, A.A., 2008, Very-high-resolution mapping of river-immersed topography by remote sensing: Progress in Physical Geography, v. 32, no. 4, p. 403-419, accessed September 3, 2014, at http://dx.doi. org/10.1177/0309133308096030.

Guenther, G.C., Cunningham, A.G., LaRocque, P.E., and Reid, D.J., 2000, Meeting the accuracy challenge in airborne lidar bathymetry: Proceedings of EARSeL-SIG-Workshop LIDAR, Dresden/FRG, June 16-17, 2000, accessed November 29, 2016, at http://www.eproceedings.org/static/ vol01_1/01_1_guenther1.pdf. 
Heidemann, H.K., 2014, Lidar base specification (ver. 1.2, November 2014): U.S. Geological Survey Techniques and Methods, book 11, chap. B4, 67 p. with appendixes. [Also available at http://dx.doi.org/10.3133/tm11B4.]

Hohenthal, Johanna, Alho, Petteri, Hyyppa, Juha, and Hyyppa, Hannu, 2011, Laser scanning applications in fluvial studies: Progress in Physical Geography, v. 35, no. 6, p. 782-809, accessed January 15, 2015, at http://dx.doi. org/10.1177/0309133311414605.

Jenson, S.K., and Dominque, J.O., 1988, Extracting topographic structure from digital elevation data for geographic information system analysis: Photogrammetric Engineering and Remote Sensing, v. 54, no. 11, p. 1593-1600, accessed August 11, 2016, at ftp://rymd.lwr.kth.se/Common/UllaM/ For_Imran/[1988]\%20jenson\%20-\%20extracting\%20topographic $\% 20$ structure $\% 20$ from $\% 20$ digital $\% 20$ elevation $\% 20$ data $\% 20$ for $\% 20$ geographic $\% 20$ information $\% 20$ system $\% 20$ analysis.pdf.

Kinzel, P.J., Legleiter, C.J., and Nelson, J.M., 2013, Mapping river bathymetry with a small footprint green lidar-Applications and challenges: Journal of the American Water Resources Association, v. 49, no. 1, p. 183-204. [Also available at http://onlinelibrary.wiley.com/doi/10.1111/ jawr.12008/full.]

Leica Geosystems, 2017, Leica Chiroptera II Bathymetric and Topographic LiDAR Sensor: accessed October 6, 2017, at http://leica-geosystems.com/products/airborne-systems/ lidar-sensors/leica-chiroptera-ii.

Leica Geosystems AG-Part of Hexagon, 2017, Leica Hawkeye III Deep Bathymetric LiDAR Sensor: accessed October 6, 2017, at http://leica-geosystems.com/products/airbornesystems/lidar-sensors/leica-hawkeye-iii.

Merwade, Venkatesh, 2012, Watershed and stream network delineation using ArcHydro tools: School of Civil Engineering, Purdue University, accessed August 10, 2016, at https:// web.ics.purdue.edu/ vmerwade/education/terrain_processing.pdf.

Miller-Corbett, Cynthia, 2016, Evaluating integration of inland bathymetry in the U.S. Geological Survey 3D Elevation Program, 2014: U.S. Geological Survey Open-File Report 2016-1126, 44 p., accessed February 17, 2017, at http:// dx.doi.org/10.3133/ofr20161126.

National Oceanic and Atmospheric Administration, National Ocean Service, 2012, BookletChart ${ }^{\mathrm{TM}}$, Delaware RiverPhiladelphia to Trenton NOAA Chart 12314: accessed September 2, 2016, at http://www.charts.noaa.gov/InteractiveCatalog/nrnc.shtml?rnc=12314.
National Park Service, 2011, Comparison of shallow water mapping technologies: 3 p., accessed August 17, 2014, at https://www.nps.gov/caco/learn/nature/upload/Copy-ofMatrix-of-mapping-technologies-for-shallow-water-mapping.pdf.

National Park Service, 2012, Delaware River Basin, National Wild and Scenic River Values: accessed October 6, 2012, at https://www.state.nj.us/drbc/library/documents/NPSreport DRBwild-scenic-river-valuesSept2012.pdf.

Optech Incorporated, 2006, Shoals-3000 Hydrographic Charting and More: accessed October 6, 2017, at http://www. geo3d.hr/download/shoals/SHOALS_3000.pdf.

RIEGL Laser Measurement Systems GmbH, 2017, Rieg1 VQ-880-G: accessed October 6, 2017, at http://www.riegl. $\mathrm{com} / \mathrm{nc} /$ products/airborne-scanning/produktdetail/product/ scanner/46/.

Tarboton, D.G., Bras, R.L., and Rodriguez-Iturbe, Ignacio, 1991, On the extraction of channel networks from digital elevation data: Hydrological Processes, v. 5, p. 81-100, accessed June 6, 2016, at http://www.neng.usu.edu/cee/faculty/dtarb/hp91.pdf.

U.S. Bureau of Reclamation, 2006, Reservoir survey and data analysis, chap. 9 of Erosion and sedimentation manual: accessed September 17, 2014, at https://www.usbr.gov/tsc/ techreferences/mands/mands-pdfs/Erosion $\% 20$ and $\% 20$ Sedimentation\%20Manual.pdf.

U.S. Geological Survey, 2013a, NHD feature catalog: accessed September 25, 2016, at http://nhd.usgs.gov/userguide. html?url=NHD_User_Guide/Feature_Catalog/NHD_Feature_Catalog.htm.

U.S. Geological Survey, 2013b, Delaware River Basin NAWQA - Geology and physiographic provinces: accessed September 13, 2016, at http://nj.usgs.gov/nawqa/delr/figs/ geol_phys.pdf.

U.S. Geological Survey, 2014a, Frequently asked questions about the NHD and WBD datasets: accessed September 22, 2016, at http://nhd.usgs.gov/Frequently+Asked+Questions+ about+the $+\mathrm{NHD}+\&+$ WBD.htm\#.

U.S. Geological Survey, 2014b, Lidar for science and resource management: accessed August 10, 2016, at http://enfo. agt.bme.hu/drupal/sites/default/files/Lidar\%20for\%20Science $\% 20$ and $\% 20$ Resource $\% 20$ Management.pdf.

U.S. Geological Survey, 2016a, Turbidity: U.S. Geological Survey Water Science School, accessed October 5, 2016, at http://water.usgs.gov/edu/turbidity.html. 
U.S. Geological Survey, 2016b, HYDROGRAPHY LOCALRES_FLOWLINE_CLASSIFIED_NHD_IN_-Streams, rivers, canals, ditches, artificial paths, connectors, pipelines, and intermittent streams in watersheds of Indiana (U.S. Geological Survey, 1:2,400, Line Shapefile): Indianapolis, Indiana, U.S. Geological Survey, accessed September 19, 2017, at http://maps.indiana.edu/metadata/ Hydrology/Water_Bodies_Flowlines_Classified_LocalRes. html\#Identification_Information.

U.S. Geological Survey, 2016c, 3DEP: U.S. Geological Survey, The National Map, Elevation Products, accessed August 29, 2016, at http://viewer.nationalmap.gov/ basic/?how To=true.

U.S. Geological Survey, 2017, National Water Information System-Web interface: accessed June 24, 2017, at https:// doi.org/10.5066/F7P55KJN.

Watkins, D.W., Jr., ed., 2017, Journal of Water Resources Planning and Management-Aims and scope: American Society of Civil Engineers, accessed February 4, 2017, at http://ascelibrary.org/page/jwrmd5/editorialboard.

White, K.E., and Kratzer, T.W., 1993, Determination of travel time in the Delaware River, Hancock, New York, to the Delaware Water Gap by use of a conservative dye tracer: U.S. Geological Survey Water-Resources Investigations Report 93-4203, 54 p. [Also available at https://pubs.er.usgs.gov/ publication/wri934203.]

Wright, C.W., Fredericks, Xan, Troche, R.J., Klipp, E.S., Kranenburg, C.J., and Nagle, D.B., 2014, EAARL-B coastal topography-Eastern New Jersey, Hurricane Sandy, 2012; first surface (version 1.1, August 18, 2014): U.S. Geological Survey Data Series 767, accessed September 17, 2014, at https://pubs.usgs.gov/ds/767/. [Also available at https:// dx.doi.org/10.3133/ds767.]

Wright, C.W., Kranenburg, C.J., Troche, R.J., Mitchell, R.W., and Nagle, D.B., 2016, Depth calibration of the experimental advanced airborne research lidar, EAARL-B: U.S. Geological Survey Open-File Report 2016-1048, 23 p., accessed June 13, 2016, at http://dx.doi.org/10.3133/ ofr20161048. 
For more information about this publication, contact

Director, USGS National Geospatial Technical Operations Center 1400 Independence Road

Rolla, MO 65401

(573) 308-3500

For additional information visit https://ngtoc.usgs.gov

Publishing support provided by the

Rolla Publishing Service Center 



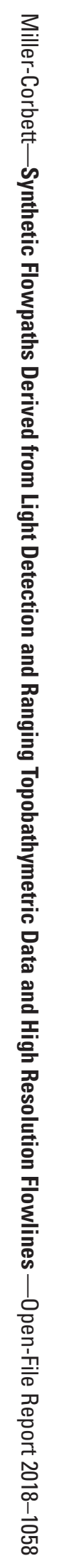

